IZA DP No. 8387

Can Elected Minority Representatives Affect Health Worker Visits? Evidence from India

Elizabeth Kaletski

Nishith Prakash

August 2014

Forschungsinstitut zur Zukunft der Arbeit Institute for the Study of Labor 


\title{
Can Elected Minority Representatives Affect Health Worker Visits? Evidence from India
}

\author{
Elizabeth Kaletski \\ University of Connecticut \\ Nishith Prakash \\ University of Connecticut, \\ IZA, CReAM and INSIDE
}

Discussion Paper No. 8387

August 2014

\author{
IZA \\ P.O. Box 7240 \\ 53072 Bonn \\ Germany \\ Phone: +49-228-3894-0 \\ Fax: +49-228-3894-180 \\ E-mail: iza@iza.org
}

\begin{abstract}
Any opinions expressed here are those of the author(s) and not those of IZA. Research published in this series may include views on policy, but the institute itself takes no institutional policy positions. The IZA research network is committed to the IZA Guiding Principles of Research Integrity.

The Institute for the Study of Labor (IZA) in Bonn is a local and virtual international research center and a place of communication between science, politics and business. IZA is an independent nonprofit organization supported by Deutsche Post Foundation. The center is associated with the University of Bonn and offers a stimulating research environment through its international network, workshops and conferences, data service, project support, research visits and doctoral program. IZA engages in (i) original and internationally competitive research in all fields of labor economics, (ii) development of policy concepts, and (iii) dissemination of research results and concepts to the interested public.
\end{abstract}

IZA Discussion Papers often represent preliminary work and are circulated to encourage discussion. Citation of such a paper should account for its provisional character. A revised version may be available directly from the author. 
IZA Discussion Paper No. 8387

August 2014

\section{ABSTRACT}

\section{Can Elected Minority Representatives Affect Health Worker Visits? Evidence from India*}

This paper examines the relationship between elected minority representatives, Scheduled Castes and Scheduled Tribes, and health worker visits in rural India. We estimate the effect of minority representation on the frequency of visits to villages by health workers by exploiting the state variation in the share of seats reserved for the two groups in state legislative assemblies mandated by the Constitution of India. Using data from state and village level surveys on fifteen major Indian states, we find that Schedule Tribe representatives increase the frequency of visits by both doctors and mobile medical units. On the other hand, Scheduled Caste representatives have a tendency to decrease the frequency of visits by mobile medical units. Potential explanations for the differential impact of SC and ST representatives are also explored, including geographic isolation, support for the Congress Party, and relative population shares.

JEL Classification: I18, I38, J15

Keywords: affirmative action, minorities, health, public goods provision, India

Corresponding author:

Nishith Prakash

Department of Economics and Human Rights Institute

University of Connecticut

Storrs, CT 06269-1063

USA

E-mail: nishith.prakash@uconn.edu

\footnotetext{
${ }^{*}$ We are responsible for any errors that may remain.
} 


\section{Introduction}

Despite the rapid growth India has experienced in the past few decades, health outcomes remain poor for a large portion of the population. This inequity stems partly from historical discrimination which has created large socioeconomic deficits for disadvantaged groups, including minorities, the poor, and rural populations. Despite the fact that health outcomes significantly impact both current and future populations, provision of health care in India remains dismal. Public service delivery, including the frequency of visits to villages by health workers, is plagued by issues of absenteeism, resulting in poorer outcomes, particularly in areas most in need of improvement.

In response to these ingrained inequalities, which also include an under-representation in politics and public sector employment, the Indian Constitution mandates that a certain share of seats be reserved in the state legislative assemblies and the national parliament (i.e. the Lok Sabha or the lower house) for two minority groups, namely Scheduled Castes (SCs) and Scheduled Tribes (STs). These elected representatives have the mandate and constitutional powers to address gaps in public goods provision, for example, health, education etc., through efficient provision of public good outcomes. Previous studies have estimated the impact of political reservation for minorities on a variety of policy outcomes including welfare spending, land reforms, employment, and poverty. Despite the importance of these studies, to the best of our knowledge there is no empirical evidence on how these policies impact provision of health services. This paper adds to the existing literature by examining the relationship between elected minority representatives and the frequency of visits by doctors and mobile medical units in rural villages in India.

Elected representatives have the potential to affect health outcomes generally, and public

service delivery outcomes more formally, as a quarter of all legislators in India come from reserved constituencies. These minority representatives can directly address poor health outcomes by increasing health expenditures or by addressing absenteeism among health workers. 
The latter is particularly likely to be true since Members of the Legislative Assembly (MLA) are elected for the purpose of catering to their constituency. Voters have the ability to voice their concerns directly to their MLA, who can then use their legislative and executive powers to address the concerns, including reprimanding the concerned district official or bureaucrat. On the other hand, if workers, district administrators, and MLAs are part of the same caste, absenteeism may increase as doctors or health workers may feel a sense of protection and security in their job. ${ }^{1}$ There is evidence that elected representatives have the ability to both improve outcomes for individuals (Iyer et al., 2011) and exasperate existing issues (Mishra, 2014). Thus, whether or not these elected officials actually impact the frequency of visits by health workers is an empirical question.

However, estimating the impact elected officials could have on health service delivery is difficult because minority representation itself is likely endogenous to the outcome variables of interest. This could occur because the percentage of minorities elected in certain areas or states may vary in ways that also impact our outcomes of interest. In order to address the endogeneity concerns we use the empirical strategy established in Pande (2003) and implemented in Chin and Prakash (2011) and Kaletski and Prakash (2014), which involves isolating the effect of other omitted variables. Similar to the constraints in Kaletski and Prakash (2014), we are limited by the availability of only two rounds of nationally representative rural household data from 1982 and 1999. Thus in our empirical strategy we only exploit the across-state variation in the share of seats reserved for the disadvantaged minorities. It should be noted that due to these restrictions we cannot establish the causality or pin down the mechanisms, but simply perform a reduced form estimation of the relationship. We further elaborate on the empirical strategy in Section 3. Our main findings indicate that ST representatives are associated with increased frequency of visits by both doctors and mobile medical units, while SC representatives tends to decrease the frequency of visits by mobile medical units. We further explore potential explanations for the differential impact of SC

\footnotetext{
${ }^{1}$ Teachers and health workers play a vital role by acting as polling officers during state elections in India.
} 
and ST elected officials.

The literature up to this point has provided several potential mechanisms through which this could occur. For example, Pande (2003) uses data from sixteen major Indian states from 1960-1992, to estimate the impact of SC and ST political representatives on general and targeted government policies separately. ${ }^{2}$ She finds that ST representatives increase spending on ST welfare programs and lowers educational and overall government spending, while SC representatives increase the number of state government jobs reserved for minorities. This is particularly important for the present study as this change in the allocation of resources is likely to impact the provision of public goods, including the availability of medicines and medical equipments and frequency of visits by health workers to villages. In particular, the increase in welfare spending could come in the form of increased resources for doctors and medical workers, improving the quality of outcomes, while also encouraging a decline in absenteeism.

In another related paper, Krishnan (2007) examines whether districts represented by more minority legislators provide different public goods relative to non-minority representatives. She examines that availability of health and educational facilities, with a specific focus on primary schools. She finds that SC legislators improve access to primary schools, which benefit both SC and non-SC groups, while ST legislators perform similarly to legislators in unreserved constituencies. Although, it is unclear how these results will translate into a different form of public good provision, namely the frequency of visits by health workers, since health is a known concern for poor, minority, and rural populations, minority representatives may use their power to shift resources in order to improve outcomes. Additional potential mechanisms will be discussed further below. ${ }^{3}$

\footnotetext{
${ }^{2}$ In Pande (2003) general government policies include total per capita state spending, total education spending, and whether or not a land reform act occurs. Targeted policies include the fraction of government spending going towards SC and ST welfare programs, along with job quotas for those groups.

${ }^{3}$ In other papers regarding political reservation, Kaletski and Prakash (2014) examine the relationship between minority representation and child labor, finding that ST reservation decreases the total number of children working at the household level, while SC reservation tends to increase child labor. Chin and Prakash (2011) find that increasing the share of minority seats reserved for STs reduces overall poverty, while SC reservation has no impact on poverty. Several studies have also explored the impact of women's and local
} 
Previous literature has focused on how state level political representatives impact aggregate policy outcomes and provides several potential links between reservation and public goods allocation. We are not aware of any paper that examines the effect of these elected minorities on health outcomes generally, nor the frequency of visits by health workers more specifically. This paper then adds to the existing literature by exploring the impacts of political representation on this village level outcome. The remainder of this paper proceeds as follows: Section 2 discusses the background and potential links between representatives, health, and absenteeism. Section 3 presents the empirical framework and Section 4 describes the data. Section 5 reports the main empirical results, while Section 6 discusses the results on the heterogeneous effects of representation for different minority groups. Section 7 concludes.

\section{Background}

\subsection{Potential Links between Elected Minority Representatives and Visits By Health Workers}

Elected representatives have the potential to affect policy outcomes as a quarter of all legislators in India come from reserved constituencies. However, as discussed before, the relationship between these elected representatives and health worker visits to villages is an empirical question. It may simply be the case that they do not perform any differently than

level SC and ST reservation. For example, Chattopadhyay and Duflo (2004) find that women representatives in the Gram Panchayat (bottom tier of local government) tend to shift spending towards the allocation of local public goods, such as drinking water and roads. On the other hand, Bardhan et al. (2010) find no significant effects of women pradhan (mayor) reservations on the same public policy aspects in West Bengal. Mookherjee (2012) provides a summary of these, along with similar papers, and concludes that it is still unclear if women reservations will have long run impacts on policies. In the case of SC and ST reservation at the village level, SC and ST pradhans increase the probability that households in that village have a toilet, electricity connection, and private waterline (Besley, Pande, Rahman and Rao, 2004), as well as increase the benefits from the local government for housing construction and improvements (Bardhan, Mookherjee and Parra Torrado, 2010). Similarly, having an SC pradhan increases public goods to areas where SCs are concentrated (Duflo, Fischer and Chattopadhyay, 2008). 
elected officials in unreserved constituencies. Krishnan (2007) found this to be the case for ST representatives in terms of public allocation of schools and health facilities. Related to this idea, a lack of impact may also be due to the fact that despite its high prevalence, education and health worker absence is simply not a major election issue. Part of this could simply be because health and education workers may be a mobilized group that votes based on their own interests, while those using the services, namely the poor, are less likely to have a political voice (Chaudhury et al., 2006).

It is also possible that these elected representatives simply have no impact on this particular outcome. This could be the case if state level representatives are unaware of the problems that arise at the village and household level. If they are not present in these villages, or not in direct contact with their constituents, they may not be aware of the absenteeism among health workers. Further, even if they are aware, it is possible that they have no direct control over these particular outcomes. As discussed above, they are limited by the responsibilities that are laid out in the Indian Constitution. In addition bureaucrats are autonomous public servants in India and it is not easy to control or fire. Lastly, even if a transfer of funds for the purpose of education and health occurred, those funds are much more likely to go towards increasing the quantity of goods, rather than the actual quality (Chaudhury et al., 2006). ${ }^{4}$

On the other hand, elected representatives have the potential to positively impact the frequency of visits by health workers. One potential channel through which this may occur is through the Chief Minister of the State. When an elected representatives party is in power he (she) has more control over the bureaucracy, therefore allowing the Chief Minister to make major decisions regarding finances, development, and other important factors. If he (she) sees fit, he (she) can induce bureaucrats or health workers directly to act in certain ways in order to increase the frequency of visits to the villages. However, elected representatives may act in their own interest as well. If they simply care about their constituents and recognize the

\footnotetext{
${ }^{4}$ For instance, by building additional schools, rather than ensuring teachers show up and actually teach students.
} 
importance of improved health and its' longer term consequences, they can enact polices to improve the situation and address absenteeism more formally. This can be done in a variety of ways, including legislative changes or through welfare schemes. Pande (2003) has already shown that ST representatives increase spending on ST welfare programs, some of which is potentially allocated towards improving health outcomes. Although these funds could be used for multiple purposes, increasing resources for doctors and other medical professionals would then make overall health care more effective. There is evidence that particularly for doctors, absence is negatively and significantly correlated with state per capita income, which could be a direct result of income improving the quality of services (Chaudhury et al., 2006). Thus providing greater resources makes it easier for health professionals to do necessary tasks, increasing their frequency of visits to villages for various purposes.

In the specific case of STs, elected representatives may find it especially efficient to increase the frequency of visits by medical workers to villages. ST populations tend to be homogeneous and geographically isolated, making it easier to directly target and improve outcomes for their own caste members. Further, if the caste of the elected official is the same as the caste of any particular health worker, that worker may decrease their absence in order to help members of their own social group. Thus ST representatives have even greater incentives to enact policies that directly increase the frequency of visits by health workers.

In stark contrast, elected representatives could also have a negative effect on the frequency of visits by medical professionals to villages. This may occur if politicians actually exacerbate the issues of worker absence. For instance, if a bureaucrat or health worker is of the same caste as the elected politician, they may feel a sense of job security or this could also be because of the political patronage. There could be the implicit assumption of protection, where workers no longer fear being fired and feel as though no one will actually hold them accountable, thus increasing the already large issue of absence in the education and health sectors. This is likely to be especially true among SCs as they are more politically active and play a major role in government formation than their ST counterparts. In recent years, many 
SC and OBC members have been elected as State Chief Minsters, increasing their power and influence. For example, in May of 2014, millions celebrated the election of an individual from one of the lowest SC castes as the Chief Minister in the state of Bihar (Nelson, 2014). This may make SC members feel particularly secure and optimistic as someone in a position of power will support and protect them out of loyalty to their social group.

As an example of this tendency, The Times of India has reported that those districts of Uttar Pradesh under Samajwadi Party's rule have seen an increase in police stations being headed by Yadav officers, in conjunction with increased crime and police slackness. ${ }^{5}$ Although direct causation or correlation has not been established, it is speculated that police investigations have been influenced by the caste of both the criminals and law enforcement (Mishra, 2014). On a similar, but more hopeful note, Iyer et al. (2011) find evidence that female representation in local government increases the number of crimes reported against women, without increasing the incidence of crime. They argue that female representatives empower women by giving them a voice and helping to change lax police behavior (Iyer et al., 2011). Thus depending on the specific context, social groups involved, and preferences of individuals, elected representatives have the potential to both exacerbate and improve health outcomes. The impact of elected representatives on the frequency of visits by health workers is then not an election issue, but depends on the potential mechanisms through which officials can impact public service delivery directly and indirectly.

\subsection{Health and Health Worker Absenteeism in India}

Health is well established as an important issue throughout the world, but particularly among the poorest groups in India, including minorities and rural populations. As Muralidharan (2007) points out, despite the recent rapid growth that has occurred in India, inclusive growth remains an issue, which necessitates providing high quality health (and education) services to all citizens. It is further acknowledged that improving health outcomes is a rec-

\footnotetext{
${ }^{5}$ Yadavization of UP cops behind anarchy published in The Times of India on June 7th, 2014.
} 
ognized desire of many poor households. According to a survey in Poor Economics the most frequent source of stress for individuals in Udaipur is their own health and the health of their relatives (Banerjee and Duflo, 2011). Although the data available for this study allow them to distinguish between visits by health workers for various reasons, in this paper we will focus on visits related to family planning and health, fertility, and malaria eradication. ${ }^{6,7}$

The reason for the focus on fertility and family planning is due to the fact that fertility rates and health risk remain extremely high, particularly among the poorest populations in India. For example, $99 \%$ of all maternal deaths occur in developing countries with $20 \%$ of those pregnancy and delivery related deaths occurring within India itself (WHO, 2012). High fertility rates further result in decreased human capital investment, particularly as it relates to child schooling, and slower economic growth (The World Bank, 2010). Thus family planning knowledge and resources help to resolve many of these issues and ensure increased health for both mothers and children. Additionally, malaria is established as an important contributor to high death rates and leaves lasting long run consequences on exposed populations. Malaria has been linked to lower economic growth (Gallup and Sachs, 2001), while eradication increases lifetime schooling and productivity for children (Barreca, 2010; Lucas, 2010), along with adult literacy and income (Bleakley, 2010). Further despite eradication increasing fertility (Lucas, 2013), it has also been shown to increases female educational attainment (Lucas, 2010).

Due to the recognized desire of improved health, on average, 6 percent of monthly expenditure in extremely poor households in rural India continues to go towards health, with large amounts being spent on single health events that require borrowing funds from moneylenders at high rates (Banerjee and Duflo, 2011). This fact leads to the conclusion that

\footnotetext{
${ }^{6}$ These outcomes include visits for family planning education, delivering babies, children, distributing iron an vitamin pills to pregnant women, Nirodh distribution, and spraying for the purpose of malaria eradication.

${ }^{7}$ The additional results are included in Tables 10-13 of Appendix A1. These include visits to chlorinate wells, blindness prevention, central health education, and delivery of food supplements for breast feeding. These results are consistent with the tables presented in the main results section and are only included in the appendix for brevity.
} 
efficient public service delivery is an important mechanism for reducing the burden on the poorest households and improving the overall wellbeing of the population. The government is then charged with the task of efficiently providing essential goods and services to the population in order to improve overall outcomes. However, despite recognizing this, central and state governments have focused on increasing spending rather than increasing efficiency (Muralidharan, 2007).

In particular, absence among both teachers and health workers is a known issue in India and across the world. In a 2003 study conducted on a nationally representative sample of 3,000 government run schools and 1,500 primary health centers across India, it was found that 23 percent of teachers and 40 percent of health workers are absent on a typical day. Further, the authors indicate that these are actually underestimates of the problem since even workers that are present are not necessarily working. As an example, 25-30 percent of teachers who are present at school are not actually teaching (Chaudhury et al., 2006). Doctors are especially likely to be absent partly because their high skill set allows them to engage in private practice, whereas other types of workers do have the same opportunity. Further, this behavior is encouraged by the fact that disciplinary action for absence is rarely taken and teachers and health workers are almost never fired. ${ }^{8}$ In all 3,000 schools, there was only one reported case of a firing for repeated absence. This problem varies across states and is negatively correlated with the average GDP per capita of a given state. Thus absence of workers is actually highest in those states where public provision of education and health is most in need of improvement (Chaudhury et al., 2006). This is of particular concern here as we examine the frequency of visits to villages by medical professionals as our outcome of interest. Thus the question of whether state elected minority representation has any impact remains.

\footnotetext{
${ }^{8}$ Banerjee and Duflo (2011) support this argument by indicating that poor health outcomes and a lack of preventative care is partly due to government inefficiency which encourages, or at least doesn't punish, high absenteeism and low motivation among government health providers. They indicate that a 2002-2003 World Bank survey estimates an absentee rate of 43 percent among doctors and nurses in India.
} 


\subsection{Political Reservation in State Legislative Assemblies and the Role of Elected Representatives in India}

India is a federal republic with a parliamentary system of government, where the formal political structure parallels that of the national structure. The Parliament of India consists of the President of India and the two Houses - The Upper House (also called the Rajya Sabha or Council of States) and The Lower House (also called the Lok Sabha or House of the People). Those elected or nominated to either house of the Parliament are referred to as members of parliament (or MPs). The states in India follow similar structure where The Upper House is called Vidhan Parishad (or Legislative Council) and The Lower House is called the Vidhan Sabha (or Legislative Assembly). Those elected or nominated to either house of the Parliament are referred to as Member of Legislative Assembly (or MLAs). Both federal and states are divided into single-member constituencies and characterized by a first-past-thepost election system. Electors cast one vote for a candidate in their respective constituency and candidates compete in elections to win the single-member legislative constituency by plurality. Elections are scheduled to take place every 5 years; although it is possible to to have elections before the 5 -year term mostly due to shifting of political alignments. ${ }^{9}$

This paper focuses on two specific minority groups, SCs and STs, who make up $16.6 \%$ and $8.6 \%$ of the population respectively. ${ }^{10}$ SCs are those groups with low social and ritual standing in the Hindu caste hierarchy, while STs are groups identified by their tribal culture, geographic isolation, and linguistic characteristics. ${ }^{11,12}$ Both of these groups have been historically discriminated against and prevented from engaging in opportunities or claiming rights that could improve their status in Indian society. Much of this stems from discrimination

\footnotetext{
${ }^{9}$ According to the Indian Constitution, any Indian citizen who is registered as a voter and is over the age of 25 years can run for election to the Federal Government or the State Legislative Assemblies. However, candidates running for the State Legislative Assemblies should be a resident of the same state.

${ }^{10}$ These estimates are based on the 2011 Census data.

${ }^{11}$ These groups were formally referred to as untouchables or backward castes.

${ }^{12}$ The Indian Constitution, specifically the Schedule Castes and Scheduled Tribe Order of 1950, stipulates which groups are considered SCs and STs. Further, the SC and ST Orders Act of 1976 requires that SC and ST definitions be uniform across all states.
} 
in the Hindu caste system which determined that SC members took menial jobs and were restricted from owning assets. Similarly, geographic isolation and reliance on subsistence agricultural led to widespread poverty among STs (Pande, 2003).

In order to correct this historical discrimination, India has a long history of aggressive and mandated affirmative action policies aimed at increasing opportunities for disadvantaged groups in education, public sector employment and political reservation. The Constitution, effective January 26, 1950, requires representation for SCs and STs in the lower house of Parliament (Lok Sabha) and state legislative assemblies. ${ }^{13}$ More specifically, Article 332 of the Indian Constitution establishes that the number of seats reserved for SCs and STs in the state legislative assemblies is determined by the share of that group's total state population in the last preceding census. Thus the primary source of variation is the arrival of the new census population data. ${ }^{14}$

Upon the arrival of new census figures, the Delimitation Commission is then responsible for revising the number of seats reserved in each state for SCs and STs, along with designating the specific constituencies in which they are reserved. ${ }^{15}$ Additional variation arises across states due to the time lag until the Delimitation Commission revises reservations based on new population counts and the fact that changes are not actually applied until the next election, which varies randomly across states. The data used here cover 1982 and 1999, but since the 42nd amendment in 1976 suspended new delimitations until after 2000, all reserved seats are based on the 1971 census. This factor then limits us to exploiting the across-state variation using the two rounds of household data.

The elected state legislatures are largely autonomous from the central government and

\footnotetext{
${ }^{13}$ Further, decentralization of the government of India and representation of SCs and STs at the local government level was established in 1993 by the 73rd and 74th amendments. Specifically, the 73rd amendment addressed local governments in rural areas, while the 74th targets urban areas.

${ }^{14}$ It should be noted that only members of the given group can be elected to the reserved seats, but they are elected by all voters in the territory regardless of voters' social background.

${ }^{15}$ The Indian Constitution states that seats for STs are to be reserved in the constituencies where their population share is highest. On the other hand, SCs should be distributed in different parts of state, primarily where their population share is relatively high (Krishnan, 2007).
} 
their responsibilities are laid out in the Indian Constitution. These responsibilities include ensuring public order, along with overseeing public health and sanitation, intrastate roads, water, land, agriculture and industry. Additionally, education, social security and insurance, and labor are jointly determined by the central and state governments. The main channel for the state government to affect outcomes is through allocation of state level spending, establishing and enforcing laws, outlining priorities, and supervising lower government levels (Chin and Prakash, 2011). This structure leaves multiple channels through which representatives from minority groups can impact policy, the allocation of resources, and health outcomes.

\section{Empirical Strategy}

As mentioned in the previous section, elected representatives have the potential to impact the frequency of visits by health workers in various ways. Thus, it is an empirical question whether minority representatives impact public service delivery.

Following the empirical strategy established in Pande (2003) and implemented in Chin and Prakash (2011) and Kaletski and Prakash (2014), the relationship between the minority share of legislative seats and the frequency of visits by medical professionals can be estimated as:

$$
y_{v s t}=\alpha_{t}+\sigma_{r}+\beta_{1} S C \operatorname{Res}_{s}+\beta_{2} S T \operatorname{Res}_{s}+e_{v s t}
$$

where $y_{v s t}$ is the frequency of visits by health workers to village $\mathrm{v}$ in state $\mathrm{s}$ at time $\mathrm{t}$. $S C R e p_{s}$ and $S T R e p_{s}$ are the share of seats reserved for the SCs and STs in state legislative assemblies, respectively. It should be noted here that because there are almost no seats won by SCs or STs in unreserved constituencies, there is no distinction between the share of seats held by SCs and STs and the share of seats reserved. $\alpha_{t}$ and $\sigma_{r}$ are time and region fixed effects, which control for any time-invariant region characteristics and macroeconomic shocks 
or national policies that affect all states uniformly. ${ }^{16}$ The coefficients of interest here are $\beta_{1}$ and $\beta_{2}$, which estimate the effect of SC and ST elected minorities on the frequency of visits by health workers to a given village.

Estimating Equation (1) will not give the causal effect of SC and ST political representatives on public goods allocation. The first likely concern is the presence of omitted variable bias. States that elect a greater number of SC and ST state legislators are likely to be different in other ways that also affect the allocation of resources. However, given the Constitutional Order of 1950, state governments have no discretion regarding the implementation of this policy. In fact, all states must follow the same policy rule in determining minority representation. Therefore any change in SC and ST representation is exogenous to the state as they only occur based on new census counts or institutional changes from the central government.

An additional concern arises based on this policy rule. Specifically, the rule indicates that the share of seats reserved is proportional to the minority population share in the last preceding census, implying that minority population share is correlated with minority elected representatives. It could also be the case that minority population share is related to how resources are allocated within and across states. One solution to this problem is to directly control for minority population share in Equation (1).

However, if minority population share always equals the share of seats held, perfect collinearity would prevent us from estimating the impact of minority reserved seats on the frequency of visits. In order to address this issue we exploit the specific characteristics of the policy rule and its implementation process. First, we know that the policy rule is based on the last preceding census, so it is still possible to control for minority population share in state s at time t. In addition, our data are drawn from a sample after 1976 when the 42nd Amendment suspended new delimitation until 2000. Therefore the political reservations are based on the 1971 census. These factors allow us to control for both the current minority population share

\footnotetext{
${ }^{16}$ States are classified as belonging to five distinct regions: North, Northeast, South, West and East.
} 
in 1982 and 1999 along with the minority population shares in the last preceding decennial census of 1981 and 1991. Table 1 displays how current and census population, along with the actual minority representation differs by state within the sample. Thus we can separate the effect of minority census population share from minority representation and identify the impact on the frequency of visits off the variation in share of seats reserved across states for the two minority groups.

We modify Equation (1) above to estimate the following:

$y_{v s t}=\alpha_{t}+\sigma_{r}+\beta_{1} S C$ Res $_{s}+\beta_{2} S T$ Res $_{s}+\gamma_{1}$ Current Pop st $+\gamma_{2}$ Census Pop $_{s t}+\delta X_{s t}+e_{i s t}$

here Current Pop st is the minority share of the population in state s at time t and Census Popst is the minority share of the population in the last preceding census in state s at time $t$. In some specifications we further control for additional state level characteristics, $X_{s t}$. The variables in $X_{s t}$ are state level controls including per capita state income last year, a dummy for election year, rural share of the population, and the log of total state expenditure per capita. ${ }^{17}$

\section{Data}

We use data from a variety of sources to implement our empirical strategy. The primary source is two rounds of ARIS/REDS data from 1982 and 1999. ARIS/REDS is a large, nationally representative sample of rural households and villages from fifteen major states in India. ${ }^{18}$ Our key outcome variable, the frequency of visits by medical professionals, comes exclusively from the 1982 and 1999 rounds of the ARIS/REDS dataset. The village level

\footnotetext{
${ }^{17}$ All expenditures variables have been adjusted using the Indian consumer price index (CPI) and are in 1999 Indian Rupees (INR).

${ }^{18}$ The states included are Andhra Pradesh, Assam, Bihar, Gujarat, Haryana, Karnataka, Kerala, Madhya Pradesh, Maharashtra, Orissa, Punjab, Rajasthan, Tamil Nadu, Uttar Pradesh and West Bengal. As noted in Table 1, we only have data for Assam in 1999.
} 
data include 474 village-year observations in rural areas across these fifteen states.

The frequency of visits by medical professionals includes separate variables for visits by doctors, health workers, and mobile medical units for a variety of purposes. ${ }^{19}$ The purpose for visits include family planning education, delivering babies, children, distributing iron and vitamin pills to pregnant women, Nirodh distribution, malaria eradication, well chlorination, blindness prevention, central health education, and allocating food supplements for breast feeding. However, as mentioned earlier, the main results will cover family planning and malaria, while the other outcomes are shown in Appendix A1. These variables are coded in the following way: the frequency of visits equals 1 if medical personnel never visit, 2 if they only visit in emergencies, 3 if they visit less than once a year, 4 if they visit once a year, 5 if the visit once every six months, 6 if they visit once every three months, 7 if they visit once a month, and 8 if they visit once a week. Thus higher numbers indicate an increase in the frequency of visits. The descriptive statistics in Table 2 indicate that on average, medical professionals rarely visit these villages and the most frequent visits are by mobile medical units for the purpose of chlorinating wells.

Our main independent variables of interest and some of the additional controls are borrowed from Chin and Prakash (2011). These include the minority representative variables, measured as the percentage of seats in state assembly reserved for SCs and the percentage of seats in state assembly reserved for STs. These data, along with the dummy for election year which equals one when there is a state election in year t, were originally drawn from the Election Commission of India reports on state elections. The minority population share variables based on the current and last preceding census estimates, were originally drawn from the Census of India, Registrar General. The state income per capita data is from the Planning Commission, Government of India. The rural population share is drawn from Ozler et al. (1996) and was originally computed from the National Sample Survey. The expen-

\footnotetext{
${ }^{19}$ The results for health workers are omitted for brevity as there doesn't appear to be a consistent and significant relationship between political representatives and the frequency of visits by health workers.
} 
diture control for 1982 is taken from Pande (2003) and comes originally from the Reserve Bank of India Report on Currency and Finance and the Ministry of Welfare Handbook. For 1999, the expenditure control is taken solely from the Reserve Bank of India State Finances publication. ${ }^{20}$ Table 2 reports the descriptive statistics for the variables used in our estimation.

\section{$5 \quad$ Main Results}

\subsection{The Effects of Elected Minority Representatives on Frequency of Visits by Health Workers}

Our first set of results estimates the overall effect of SC and ST representatives on the frequency of visits by medical personnel at the village level. The results from Equation (2) are presented in Tables 3 through 8 . Columns 1 through 4 show the results for the frequency of visits by doctors for various purposes, while Columns 5 through 8 show the results for the frequency of visits by mobile medical units. In Columns 1 and 5, we only control for census population, while Columns 2 and 6 further add controls for the current population share. Columns 3 and 7 add additional state level controls including state income last year, an election year dummy, and the rural population share. Our preferred specifications are presented in Columns 4 and 8 and also control for total state expenditure. It should be noted here that the expenditure control is endogenous, but since the outcomes of interest are likely impacted by total state expenditure, it is included as an additional control. Its inclusion does not seem to impact the overall results. All results presented include region and year fixed effects with standard errors clustered at the state level.

\footnotetext{
${ }^{20}$ These data are calculated in the same way despite coming from different sources.
} 


\subsubsection{Family Planning}

Although Tables 3 through 7 show the results regarding the frequency of visits by medical personnel for various family planning related purposes, the story is extremely consistent across all of the tables. Using Table 3 as an example of the overall effect, Columns 1 through 8 indicate that regardless of the additional controls included, greater representation of STs in state legislative assemblies increases the frequency of visits by both doctors and mobile medical units for the purpose of family planning education. More specifically, Column 4 of Table 3 shows that a one percentage point increase in the share of elected STs in the state legislative assembly leads to a 0.337 increase in the frequency of visits by doctors for the purpose of family planning education and Column 8 shows that it leads to a 0.429 increase in the frequency of visits by mobile medical units for the same purpose.

Table 3 further indicates that greater SC representation in state legislative assemblies actually decreases the frequency of visits by mobile medical units for the purpose of family planning education. Although this decrease in visits is not associated with SC representation in every table, this relationship is consistent across Tables 4, 5 and 6 as well. Given that the negative relationship between SC representation and frequency of visits by mobile medical units does not hold across all tables, these results do not appear as robust as the results for ST representation. Despite that, they are significant in many cases and are of similar magnitude as the results of ST representation. Thus the overall impact seems to be that ST representation increases the frequency of visits by both doctors and mobile medical units for family planning purposes, while SC representation decreases the frequency of visits by mobile medical units in many cases.

The difference in outcomes across the two minority groups is particularly interesting and is consistent with other research in the area that also finds differential impacts for SC and ST representatives (Kaletski and Prakash, 2014; Chin and Prakash, 2011; Pande, 2003; Krishnan, 2007). The increase in the frequency of visits by both doctors and mobile medical 
units with ST representatives is consistent with the idea that ST representatives may allocate

resources in a way that encourages medical professionals to visit these villages. It has already been established that ST representatives increase spending on ST welfare programs (Pande, 2003) potentially providing more resources for all health professionals, leading to increasing effectiveness of medical services and decreased absence. It could also be due to the fact that STs tend to be more geographically isolated (Pande, 2003), which would allow representatives to pursue policies directly benefiting their own social group. Further they are more able to target the concerns of their constituents, which could include improving health outcomes in their community. Despite the consistency in these results, it should be noted that the frequency of visits by medical professionals for all purposes remains extremely low.

The decrease in the frequency of visits that occurs with SC elected representatives is surprising. In line with the argument above, the geographic dispersion of SC representatives may make it especially difficult for SCs to target policies and benefits towards their own group (Krishnan, 2007). Therefore instead of enacting policies that improve public service delivery overall, SC representatives instead choose to enact policies that they can ensure will directly benefit their own members, including increasing employment opportunities for SC members (Pande, 2003). Further, SC representatives may actually exacerbate the issue of absenteeism if public service workers feel a sense of protection and job security when a member of their own caste is in a position of power. One other issue to note here is that there appears to be a stronger relationship between minority representation and the frequency of visits by mobile medical units than visits by doctors. The magnitude of the coefficient is always larger in the case of mobile medical units, which may indicate that they are more likely to act in certain ways or be influenced by those is positions of power.

\subsubsection{Malaria Eradication}

Table 8 further shows the results using the frequency of visits by medical professionals for the purpose of malaria eradication. As discussed above, malaria exposure can have long 
lasting detrimental effects at the micro and macro level. The results in Column 4 indicate that a one percentage point increase in ST elected representatives is associated with a 0.215 increase in the frequency of visits by doctors, while Column 8 shows a 0.539 increase in the frequency of visits by mobile medical units. These results are consistent with what is found in Tables 3 through 7 for family planning services. However, in contrast, there is no negative relationship between the frequency of visits for malaria eradication and SC representatives. Therefore, at least to some extent, the purpose of the visit also plays an important role in the relationship between these variables.

\subsubsection{Frequency of Visits for Other Purposes}

In addition to the importance of visits by health workers for family planning and malaria eradication, Table 10 through 13 of Appendix A1 show the results for visits to chlorinate wells, blindness prevention, central health education, and distribution of food supplements for breast feeding. These results are again consistent with what is found in the results presented above. Overall, ST elected representatives are associated with an increase in the frequency of visits by both doctors and mobile medical units. In contrast, SC elected representatives are associated with a decrease in the frequency of visits by mobile medical units in many cases. However, we caution readers that there is no direct theory and we only present reduced

form results. Although it would be nice to pin down the exact mechanisms behind our results, our current data does not allow us to do so. We leave this as an additional task for future research. We further explore other potential heterogeneities behind the difference in outcomes across SC and ST representatives in Section 6 below.

\section{Exploring the Heterogeneous Impacts}

There are a number of factors that may provide insight into the differential impact across SC and ST elected representatives on the frequency of visits by medical professionals. 
In particular, in this section we explore the differences across the two groups in terms of geographic isolation, support for the Congress Party, and minority population shares. In order to explore these heterogeneities in Table 9, aggregate variables are created that measure that overall frequency of visits by doctors and mobile medical units. These variables are created based on the maximum frequency of visits to each village by doctors and mobile medical units regardless of the specific purpose for their visit. The baseline results using the full specification is shown in Column 1 of Table 9 for comparison. Panel A displays the results for the frequency of visits by doctors, while Panel B shows the results for the frequency of visits by mobile medical units. The results in this table summarize the overall heterogeneity across all results in the sample.

\subsection{Geographic Isolation}

As mentioned, STs tend to be more homogeneous, geographically isolated, and are concentrated in specific areas, while SCs are more geographically dispersed. This difference may then have differential impacts on how elected representatives will effect the frequency of visits to villages by medical professionals. For one, SC representatives may need to cater to a broader base of constituents, while ST representatives may have the ability to directly target policies towards ST members. Thus the preferences and concerns of these two groups, along with the awareness, control, and preferences of the specific representatives, may differ substantially. ST representatives may be more inclined to ensure an increase in the frequency of visits by health workers because their geographic isolation allows them to easily target increased visits to villages where their own members reside.

In order to explore this idea we allow the impacts of minority representation to vary by an index of geographic isolation. Following Chin and Prakash (2011), we use an index of isolation which measures the probability that the average minority in an Indian state will meet another minority adjusted by the prevalence of minorities in the state. In line with the discussion above, the adjusted means of these variables for SCs (.02) and STs (.13) indicate 
that STs are more much geographically isolated. ${ }^{21}$

In Column 2 of Table 9, the full specification of Equation (2) is estimated adding the interaction between minority representation and the geographic isolation variable. In comparing the coefficients in Column 2 to those in Column 1 for Panel A and B in both tables, the results indicate that the inclusion of these interaction terms does not change the overall impact of ST representatives on the frequency of visits by either doctors or mobile medical units. The coefficients on ST representatives are similar to the original results, but more interestingly, the interaction of ST representatives and geographic isolation is also positive and statistically significant in Panel B. Therefore, at least in terms of the frequency of visits by mobile medical units, geographic isolation may play a role in that as STs become more isolated, the impact of ST representation on visits increases. Based on the above discussion, this reflects the idea that as STs become more isolated ensuring visits by mobile medical units becomes easier. Further, the fact that this interaction matters only in the case of mobile medical units suggests that elected representatives may actually induce these public servants to reduce absenteeism, while they have less control over the actions of doctors.

\subsection{Support for the Congress Party}

Although the Congress Party, which is known for its' anti-poverty stance, has historically dominated Indian politics, there has been a shift of support in recent years. More specifically, although STs have tended to persistently support the party, SCs have decreased support over the years. It is possible that this shift in support has resulted in differential impacts among SCs and STs. Following Chin and Prakash (2011), we asses this impact using an interaction between minority group representatives and a dummy variable equal to one if the share of reserved seats won by Congress in the lower Parliament is at least $50 \%$.

The results shown in Column 3 of Table 9 indicate that support for the Congress party does seem to play an important role. In both panels, the coefficient on ST representatives

\footnotetext{
${ }^{21}$ See Chin and Prakash (2011) for more details on the calculation of this index.
} 
remains largely unchanged, while the coefficient on the interaction with majority Congress support is also positive and statistically significant. Thus, their alliance to Congress allows ST politicians to be more effective in increasing the frequency of visits.

\subsection{Scheduled Caste and Scheduled Tribe Population Share}

In line with the discussion in Section 6.1 above, the minority population share may more easily allow targeting of specific policies towards the representatives own group. More specifically, it's expected that representatives would impact the frequency of visits by health workers more in areas where minority population is higher. In order to explore this idea we add an interaction between minority group representatives and a minority group current population share.

In Column 4 of Panel A and B in Table 9, the results indicate that the positive significant coefficient on ST representatives remains, while the interaction with ST population share is also positive and significant for doctors. Thus as ST population share increases, the impact of ST representatives on the frequency of visits by doctors also increases. This is again in line with the idea that location and population share allow ST representatives to more easily target policies and induce action that benefits their own group.

The results in this section show that geographic isolation, support for the Congress Party, and population share all appear to impact elected minority representatives' ability increase the number of visits to villages by health workers.

\section{Discussion}

To the best of our knowledge this is the first paper to explore the impact of SC and ST elected representatives on the frequency of visits to villages by health workers. Using nationally representative household and state level data and exploiting the structure of the legislature and the timing of elections, we show that elected minorities are associated with an 
increase the frequency of visits, potentially leading to better health outcomes. Specifically, we find that ST elected representatives increase the frequency of visits by both doctors and mobile medical units, while SC elected representatives decrease the frequency of visits by mobile medical units, though the results for SCs are not robust. The results for STs are consistent regardless of the actual purpose of the visit. The results are also consistent with research which finds differential impacts across SC and ST representatives. Several reasons behind the heterogeneous impacts are also explored. In particular, geographic isolation, support for the Congress Party, and minority population share all impact public service delivery.

Given the existing gaps in health outcomes across social classes in India, ensuring efficient and effective health service delivery is an important policy goal. Up to this point, the health system has been plagued by absenteeism and a lack of adequate resources. Further, the literature has compounded evidence on the long term micro and macro implications of poor health. Thus finding ways to improve the situation, and particularly the outcomes for the poorest individuals, remains and essential component of inclusive growth and increasing quality of life. 


\section{References}

Alesina, Alberto; Baqir, Reza and Easterly, William. "Public Goods and Ethnic Divisions." Quarterly Journal of Economics, 1999, 114 (4), pp.1243-1284.

Banerjee, Abhijit and Duflo, Esther. Poor Economics: A Radical Rethinking of the Way to Fight Global Poverty. Public Affairs, New York, 2011.

Banerjee, Abhijit and Duflo, Esther. "Improving Health Care Delivery in India." 2009.

Banerjee, Abhijit and Somanathan, Rohini. "The Political Economy of Public Goods: Some Evidence from India." Journal of Development Economics, 2007, pp. 287-314.

Bardhan, Pranab; Mookherjee, Dilip and Parra Torrado, Monica L. "Impact of Political Reservations in West Bengal Local Governments on Anti-Poverty Targeting." Journal of Globalization and Development, 2010, 1 (1), Article 5.

Barreca, Alan. "The Long-Term Economic Impacts of In Utero and Postnatal Exposure to Malaria." The Journal of Human Resources, Fall 2010, 45 (4), pp. 865-892.

Bertrand, Marianne; Hanna, Rema and Sendhil Mullainathan. "Affirmative Action in Education: Evidence From Engineering College Admissions in India." Journal of Public Economics, February 2010, 94 (1-2), pp. 16-29.

Besley, Timothy; Pande, Rohini; Rahman, Lupin and Rao, Vijayendra. "The Politics of Public Good Provision: Evidence from Indian Local Governments." Journal of the European Economic Association Papers and Proceedings, April-May 2004, 2 (2-3), pp. 416-426.

Bleakley, Hoyt. "Malaria Eradication in the Americas: A Retrospective Analysis of Children Exposure." American Economic Journal: Applied Economics, 2010, 2 (2), pp. 1-45. 
Chattopadhyay, Raghabendra and Duflo, Esther. "Women as Policy Makers: Evidence from a Randomized Policy Experiment in India." Econometrica, September 2004, 72 (5), pp. 1409-1443.

Chaudhury, Nazmul; Hammer, Jeffrey; Kremer, Michael; Muralidharan, Karthik; and Rogers, F. Halsey. "Missing in Action: Teacher and Health Worker Absence in Developing Countries." Journal of Economic Perspectives, Winter 2006, 20 (1), pp. 91-116.

Chin, Aimee and Praksah, Nishith "The redistributive effects of political reservation for minorities: Evidence from India." Journal of Development Economics, 2011, 96, pp. 265-277.

Duflo, Esther. "Why Political Reservations?" Journal of the European Economic Association, April-May 2005, 3 (2-3), pp. 668-678.

Duflo, Esther; Fischer, Greg and Chattopadhyay, Raghabendra. "Efficiency and Rent Seeking in Local Government: Evidence from a Randomized Policy Experiments in India." MIT Working Paper, July 2008.

Galanter, Marc. Competing Equalities: Law and the Backward Classes in India. Berkeley: University of California Press, 1984.

Gallup, John; Sachs, Jeffrey. "The economic burden of malaria." The American Journal of Tropical Medicine and Hygiene, 2001, 64, (1), pp. 85-96.

Government of India, Ministry of Home Affairs, Office of the Registrar General and Census Commissioner. "Census 2011." 2011.

Government of India, Planning Commission. "Press Note on Poverty Estimates, 2009-10." 2012. 
Iyer, Lakshmi; Mani, Anandi; Mishra, Prachi and Topalova, Petia. "The Power of Political Voice: Women's Political Representation and Crime in India." Harvard Business School Working Paper 11-092, 2011.

Kaletski, Elizabeth; Prakash, Nishith. "Does Political Reservation doe Minorities Affect Child Labor? Evidence from India." University of Connecticut, 2014.

Krishnan, Nandini. "Political Reservation and Rural Public Good Provision in India." Boston University, 2007.

Lucas, Adrienne. "The Impact of Malaria Eradication on Fertility." Economic Development and Cultural Change, April 2013, 61 (3), pp. 607-631.

Lucas, Adrienne. "Malaria Eradication and Educational Attainment: Evidence from Paraguay and Sri Lanka." American Economic Journal: Applied Economics, April 2010, 2 (2), pp. 46-71.

Mishra, Subhash. "Yadavization of UP cops behind anarchy." The Times of India, June 7, 2014.

Mookherjee, Dilip. "Accountability of Local and State Governments in India: An Overview of Recent Research.” Boston University, 2012.

Muralidharan, Karthik. "Public Service in India: Challenges and Opportunities." University of Pennsylvania, Center for the Advanced Study of India, September 2007.

Nelson, Dean. "Indian politician's extraordinary historic rise from the lowest caste of 'untouchables' to state's chief minister." The Telegraph, May 20, 2014.

Ozler, Berk; Datt, Gaurav and Ravallion, Martin. A Database on Poverty and Growth in India, World Bank Development Research Group, Washington DC, 1996. 
Pande, Rohini. "Can Mandated Political Representation Increase Policy Influence for Disadvantaged Minorities? Theory and Evidence from India." American Economic Review, September 2003, 93 (4), pp. 1132-1151.

Reserve Bank of India, India's Central Bank. "State Finances: A Study of Budgets 20112002." 2002.

The World Bank. "Determinants and Consequences of Fertility: A Synopsis of the Evidence." 2010.

World Health Organization; Unicef; UNFPA; The World Bank "Trends in Maternal Mortality: 1990-2010." World Health Organization, 2012. 
Table 1

Summary Statistics on the Identification Strategy

\begin{tabular}{|c|c|c|c|c|c|c|c|c|c|c|}
\hline \multirow[b]{2}{*}{ State } & \multicolumn{2}{|c|}{$\begin{array}{l}\text { Representation Based on } 42^{\text {nd }} \\
\text { Amendment }\end{array}$} & \multicolumn{4}{|c|}{1981 Census } & \multicolumn{4}{|c|}{1991 Census } \\
\hline & $\begin{array}{l}\text { SC } \\
\text { Representation } \\
\text { Share }\end{array}$ & $\begin{array}{l}\text { ST } \\
\text { Representation } \\
\text { Share }\end{array}$ & $\begin{array}{l}\text { SC } \\
\text { Census } \\
\text { Pop }\end{array}$ & $\begin{array}{l}\text { SC } \\
\text { Current } \\
\text { Pop }\end{array}$ & $\begin{array}{l}\text { ST } \\
\text { Census } \\
\text { Pop }\end{array}$ & $\begin{array}{l}\text { ST } \\
\text { Current } \\
\text { Pop }\end{array}$ & $\begin{array}{l}\text { SC } \\
\text { Census } \\
\text { Pop }\end{array}$ & $\begin{array}{l}\text { SC } \\
\text { Current } \\
\text { Pop }\end{array}$ & $\begin{array}{l}\text { ST } \\
\text { Census } \\
\text { Pop }\end{array}$ & $\begin{array}{l}\text { ST } \\
\text { Current } \\
\text { Pop }\end{array}$ \\
\hline Andhra Pradesh & 13.27 & 5.10 & 14.87 & 14.97 & 5.93 & 5.97 & 15.93 & 16.14 & 6.31 & 6.54 \\
\hline Assam & 6.35 & 12.70 & & & & & 7.40 & 6.96 & 12.82 & 12.49 \\
\hline Bihar & 14.81 & 8.64 & 14.51 & 14.51 & 8.31 & 8.24 & 14.55 & 14.73 & 7.66 & 7.24 \\
\hline Gujarat & 7.14 & 14.29 & 7.15 & 7.18 & 14.22 & 14.29 & 7.41 & 7.15 & 14.92 & 14.79 \\
\hline Haryana & 18.89 & 0.00 & 19.07 & 19.13 & 0.00 & 0.00 & 19.75 & 19.43 & 0.00 & 0.00 \\
\hline Karnataka & 14.73 & 0.89 & 15.07 & 15.19 & 4.91 & 4.85 & 16.38 & 16.24 & 4.26 & 6.01 \\
\hline Kerala & 9.29 & 0.71 & 10.02 & 10.01 & 1.03 & 1.03 & 9.92 & 9.83 & 1.10 & 1.14 \\
\hline Madhya Pradesh & 13.75 & 23.44 & 14.10 & 14.15 & 22.97 & 23.00 & 14.55 & 14.31 & 23.27 & 23.23 \\
\hline Maharashtra & 6.25 & 7.64 & 7.14 & 7.46 & 9.19 & 9.20 & 11.09 & 10.37 & 9.27 & 8.94 \\
\hline Orissa & 14.97 & 23.13 & 14.66 & 14.81 & 22.43 & 22.41 & 16.20 & 16.46 & 22.21 & 22.15 \\
\hline Punjab & 24.79 & 0.00 & 26.87 & 27.01 & 0.00 & 0.00 & 28.31 & 28.75 & 0.00 & 0.00 \\
\hline Rajasthan & 16.50 & 12.00 & 17.04 & 17.07 & 12.21 & 12.23 & 17.29 & 17.18 & 12.44 & 12.54 \\
\hline Tamil Nadu & 17.95 & 1.28 & 18.35 & 18.43 & 1.07 & 1.07 & 19.18 & 19.04 & 1.03 & 1.04 \\
\hline Uttar Pradesh & 21.65 & 0.24 & 21.16 & 21.14 & 0.21 & 0.21 & 21.05 & 21.00 & 0.21 & 0.21 \\
\hline West Bengal & 20.07 & 5.78 & 21.99 & 22.15 & 5.51 & 5.52 & 23.62 & 23.13 & 5.59 & 5.52 \\
\hline
\end{tabular}

Notes: The actual seats reserved must be an integer. The SC and ST political reservation variable is based on the 1971 census and was later revised due to 42nd Constitutional Amendment. The SC and ST census population comes from 1981 and 1991 census respectively, while SC and ST current population is calculated using last preceding census and interpolated linearly as in Pande (2003). 
Table 2

Descriptive Statistics

\begin{tabular}{|c|c|c|c|c|}
\hline Variable & Mean & Standard deviation & Min & Max \\
\hline \multicolumn{5}{|l|}{ Frequency of Visits by } \\
\hline Doctors for Malaria & 1.81 & 1.81 & 1 & 8 \\
\hline Mobile Medical Units for Malaria & 1.70 & 1.67 & 1 & 8 \\
\hline Doctors for Family Planning & 1.98 & 2.06 & 1 & 8 \\
\hline Mobile Medical Units for Family Planning & 1.81 & 1.85 & 1 & 8 \\
\hline Doctors for Delivering Babies & 1.70 & 1.72 & 1 & 8 \\
\hline Mobile Medical Units for Delivering Babies & 1.49 & 1.48 & 1 & 8 \\
\hline Doctors for Children & 1.37 & 1.30 & 1 & 8 \\
\hline Mobile Medical Units for Children & 1.27 & 1.14 & 1 & 8 \\
\hline Doctors for Pregnancies & 1.91 & 2.03 & 1 & 8 \\
\hline Mobile Medical Units for Pregnancies & 1.62 & 1.68 & 1 & 8 \\
\hline Doctors for Nirodh Distribution & 1.65 & 1.78 & 1 & 8 \\
\hline Mobile Medical Units for Nirodh Distribution & 1.57 & 1.65 & 1 & 8 \\
\hline Doctors to Chlorinate Wells & 1.56 & 1.62 & 1 & 8 \\
\hline Mobile Medical Units to Chlorinate Wells & 3.90 & 2.77 & 1 & 8 \\
\hline Doctors for Blindness Prevention & 1.65 & 1.64 & 1 & 8 \\
\hline Mobile Medical Units for Blindness Prevention & 1.47 & 1.38 & 1 & 8 \\
\hline Doctors for General Education & 1.66 & 1.68 & 1 & 8 \\
\hline Mobile Medical Units for General Education & 1.52 & 1.54 & 1 & 8 \\
\hline Doctors for Food Supplements & 1.30 & 1.16 & 1 & 8 \\
\hline Mobile Medical Units for Food Supplements & 1.39 & 1.41 & 1 & 8 \\
\hline \multicolumn{5}{|l|}{ Minority political reservation (\%) } \\
\hline SC share elected representatives & 15.01 & 5.25 & 6.25 & 24.79 \\
\hline ST share elected representatives & 7.87 & 8.05 & 0.00 & 23.44 \\
\hline \multicolumn{5}{|l|}{ Minority population share controls (\%) } \\
\hline SC census population share & 15.92 & 5.27 & 7.14 & 28.31 \\
\hline ST census population share & 8.28 & 7.75 & 0.00 & 23.27 \\
\hline SC current population share & 15.89 & 5.32 & 6.96 & 28.75 \\
\hline ST current population share & 8.32 & 7.71 & 0.00 & 23.23 \\
\hline \multicolumn{5}{|l|}{ State controls } \\
\hline Log of state income per capita last year & 7.19 & 0.39 & 6.41 & 8.01 \\
\hline Election year dummy & 0.18 & 0.39 & 0.00 & 1.00 \\
\hline Rural population share (\%) & 74.29 & 7.8 & 58.31 & 88.08 \\
\hline Log of total state expenditure per capita & 7.52 & 0.44 & 6.73 & 8.38 \\
\hline Observations & 474 & & & \\
\hline
\end{tabular}

Notes: State-year data for 15 major India states from 1982 and 1999. 
Table 3

Effect of minority political reservation on public service delivery

\begin{tabular}{|c|c|c|c|c|c|c|c|c|}
\hline & \multicolumn{4}{|c|}{ Visits by Doctors for Family Planning } & \multicolumn{4}{|c|}{ Visits by Mobile Medical Units for Family Planning } \\
\hline & (1) & $(2)$ & $(3)$ & $(4)$ & $(5)$ & $(6)$ & (7) & $(8)$ \\
\hline \multirow[t]{2}{*}{ SC representative share } & 0.119 & 0.016 & -0.041 & -0.042 & $-0.344^{* * *}$ & $-0.376^{* * *}$ & $-0.405^{* * *}$ & $-0.409 * * *$ \\
\hline & $(0.078)$ & $(0.073)$ & $(0.128)$ & $(0.129)$ & $(0.104)$ & $(0.101)$ & $(0.121)$ & $(0.116)$ \\
\hline ST representative share & $(0.061)$ & $(0.063)$ & $(0.051)$ & $(0.052)$ & $(0.131)$ & $(0.131)$ & $(0.064)$ & $(0.058)$ \\
\hline SC census pop share & -0.132 & $-1.488^{* * *}$ & $-1.378^{* * *}$ & $-1.401^{* * *}$ & $0.302^{* *}$ & -0.798 & -0.784 & -0.91 \\
\hline ST census pop share & $(0.059)$ & $(0.185)$ & $(0.247)$ & $(0.245)$ & $(0.138)$ & $(0.308)$ & $(0.358)$ & $(0.356)$ \\
\hline \multirow[t]{2}{*}{ SC current pop share } & & $1.426^{* * *}$ & $1.357^{* * *}$ & $1.377^{* * *}$ & & $1.125^{*}$ & 1.113 & $1.223^{*}$ \\
\hline & & $(0.316)$ & $(0.422)$ & $(0.431)$ & & $(0.571)$ & $(0.716)$ & $(0.692)$ \\
\hline \multirow[t]{2}{*}{ ST current pop share } & & $1.058^{* * *}$ & $1.261^{* * *}$ & $1.262^{* * *}$ & & -0.085 & 0.181 & 0.189 \\
\hline & & $(0.152)$ & $(0.209)$ & $(0.208)$ & & $(0.258)$ & $(0.331)$ & $(0.337)$ \\
\hline \multirow[t]{2}{*}{ Rural population share } & & & -0.012 & -0.014 & & & $-0.060^{* *}$ & $-0.070^{* *}$ \\
\hline & & & $(0.022)$ & $(0.022)$ & & & $(0.024)$ & $(0.025)$ \\
\hline \multirow[t]{2}{*}{ Total state expenditure } & & & & -0.145 & & & & -0.809 \\
\hline & & & & $(0.988)$ & & & & $(0.939)$ \\
\hline \multirow[t]{2}{*}{ Constant } & $1.136^{* * *}$ & $2.522^{* * *}$ & 3.836 & 4.383 & $1.032^{*}$ & $1.585^{* *}$ & 9.177 & $12.187^{* *}$ \\
\hline & $(0.342)$ & $(0.201)$ & $(5.778)$ & $(6.393)$ & $(0.521)$ & $(0.568)$ & $(6.009)$ & $(5.145)$ \\
\hline Region and year fixed effects & YES & YES & YES & YES & YES & YES & YES & YES \\
\hline Number of observations & 473 & 473 & 473 & 473 & 474 & 474 & 474 & 474 \\
\hline R-squared & 0.08 & 0.11 & 0.12 & 0.12 & 0.1 & 0.11 & 0.14 & 0.14 \\
\hline
\end{tabular}

Notes: Standard errors clustered by state are in parentheses.

Asterisks denote significance: * significant at $10 \%$; ${ }^{* *}$ significant at $5 \%$; ${ }^{* *}$ significant at $1 \%$ 
Table 4

Effect of minority political representation on public service delivery

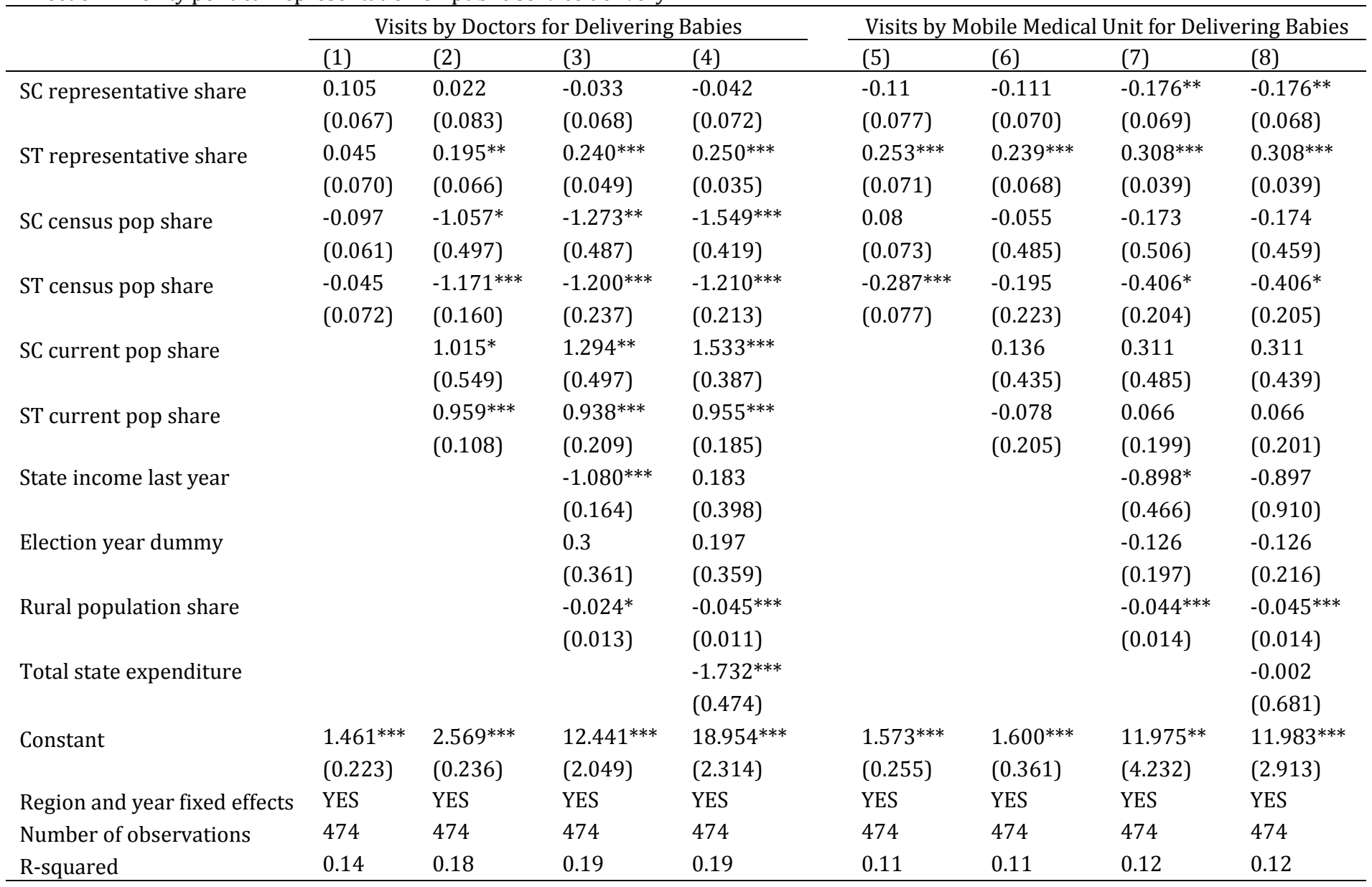

Notes: Standard errors clustered by state are in parentheses.

Asterisks denote significance: * significant at $10 \%$; ** significant at $5 \%$; ** significant at $1 \%$ 
Table 5

Effect of minority political representation on public service delivery

\begin{tabular}{|c|c|c|c|c|c|c|c|c|}
\hline & \multicolumn{4}{|c|}{ Visits by Doctors for Children } & \multicolumn{4}{|c|}{ Visits by Mobile Medical Units for Children } \\
\hline & $(1)$ & $(2)$ & $(3)$ & $(4)$ & $(5)$ & $(6)$ & $(7)$ & $(8)$ \\
\hline \multirow[t]{2}{*}{$\mathrm{SC}$ representative share } & 0.009 & -0.066 & -0.009 & -0.013 & $-0.220^{* * *}$ & $-0.209^{* * *}$ & $-0.220^{* * *}$ & $-0.223^{* * *}$ \\
\hline & $(0.053)$ & $(0.044)$ & $(0.041)$ & $(0.043)$ & $(0.073)$ & $(0.060)$ & $(0.053)$ & $(0.050)$ \\
\hline \multirow[t]{2}{*}{ ST representative share } & -0.083 & $0.098^{* * *}$ & $0.066^{* *}$ & $0.072^{* * *}$ & $0.137^{* *}$ & $0.130^{* *}$ & $0.178^{* * *}$ & $0.181^{* * *}$ \\
\hline & $(0.051)$ & $(0.032)$ & $(0.022)$ & $(0.017)$ & $(0.063)$ & $(0.058)$ & $(0.031)$ & $(0.030)$ \\
\hline \multirow[t]{2}{*}{ SC census pop share } & -0.018 & -0.423 & -0.509 & $-0.694^{* *}$ & $0.181^{* *}$ & 0.427 & 0.326 & 0.22 \\
\hline & $(0.046)$ & $(0.353)$ & $(0.305)$ & $(0.241)$ & $(0.064)$ & $(0.375)$ & $(0.375)$ & $(0.453)$ \\
\hline \multirow[t]{2}{*}{ ST census pop share } & $0.100 *$ & $-1.235^{* * *}$ & $-1.002^{* * *}$ & $-1.007^{* * *}$ & $-0.128 *$ & -0.068 & -0.169 & -0.172 \\
\hline & $(0.054)$ & $(0.050)$ & $(0.120)$ & $(0.109)$ & $(0.066)$ & $(0.124)$ & $(0.148)$ & $(0.146)$ \\
\hline \multirow[t]{2}{*}{ SC current pop share } & & 0.453 & 0.497 & $0.656^{* * *}$ & & -0.254 & -0.146 & -0.055 \\
\hline & & $(0.387)$ & $(0.310)$ & $(0.214)$ & & $(0.363)$ & $(0.342)$ & $(0.420)$ \\
\hline \multirow[t]{2}{*}{ ST current pop share } & & $1.139^{* * *}$ & $0.939 * * *$ & $0.949^{* * *}$ & & -0.052 & 0.009 & 0.015 \\
\hline & & $(0.038)$ & $(0.110)$ & $(0.092)$ & & $(0.110)$ & $(0.136)$ & $(0.138)$ \\
\hline \multirow[t]{2}{*}{ State income last year } & & & 0.125 & $0.975^{* * *}$ & & & $-0.516^{*}$ & -0.03 \\
\hline & & & $(0.212)$ & $(0.324)$ & & & $(0.242)$ & $(0.639)$ \\
\hline \multirow[t]{2}{*}{ Election year dummy } & & & $0.425^{*}$ & $0.361^{*}$ & & & -0.036 & -0.073 \\
\hline & & & $(0.208)$ & $(0.189)$ & & & $(0.161)$ & $(0.165)$ \\
\hline \multirow[t]{2}{*}{ Rural population share } & & & $0.018^{* *}$ & 0.003 & & & $-0.036^{* *}$ & $-0.044^{* * *}$ \\
\hline & & & $(0.007)$ & $(0.009)$ & & & $(0.012)$ & $(0.010)$ \\
\hline \multirow[t]{2}{*}{ Total state expenditure } & & & & $-1.168^{* * *}$ & & & & -0.669 \\
\hline & & & & $(0.288)$ & & & & $(0.676)$ \\
\hline \multirow[t]{2}{*}{ Constant } & $1.144^{* * *}$ & $2.055^{* * *}$ & -0.494 & $3.955^{*}$ & $0.954^{* * *}$ & $0.787^{* * *}$ & $7.588^{* * *}$ & $10.129^{* * *}$ \\
\hline & $(0.067)$ & $(0.172)$ & $(2.029)$ & $(2.118)$ & $(0.174)$ & $(0.233)$ & $(2.532)$ & $(2.281)$ \\
\hline Region and year fixed effects & YES & YES & YES & YES & YES & YES & YES & YES \\
\hline Number of observations & 469 & 469 & 469 & 469 & 470 & 470 & 470 & 470 \\
\hline R-squared & 0.16 & 0.23 & 0.24 & 0.25 & 0.06 & 0.06 & 0.07 & 0.07 \\
\hline
\end{tabular}

Notes: Standard errors clustered by state are in parentheses.

Asterisks denote significance: * significant at $10 \%$; ** significant at $5 \%$; ** significant at $1 \%$ 
Table 6

Effect of minority political representation on public service delivery

\begin{tabular}{|c|c|c|c|c|c|c|c|c|}
\hline & \multicolumn{4}{|c|}{ Visits by Doctors for Pregnancies } & \multicolumn{4}{|c|}{ Visits by Mobile Medical Units for Pregnancies } \\
\hline & $(1)$ & $(2)$ & $(3)$ & $(4)$ & $(5)$ & $(6)$ & $(7)$ & $(8)$ \\
\hline \multirow[t]{2}{*}{$\mathrm{SC}$ representative share } & 0.06 & -0.045 & -0.064 & -0.07 & -0.187 & -0.198 & $-0.375^{* * *}$ & $-0.359^{* * *}$ \\
\hline & $(0.070)$ & $(0.058)$ & $(0.072)$ & $(0.078)$ & $(0.121)$ & $(0.134)$ & $(0.116)$ & $(0.092)$ \\
\hline \multirow[t]{2}{*}{ ST representative share } & 0.065 & $0.254^{* * *}$ & $0.242^{* * *}$ & $0.249^{* * *}$ & $0.316^{* * *}$ & $0.298^{* * *}$ & $0.385^{* * *}$ & $0.369^{* * *}$ \\
\hline & $(0.051)$ & $(0.025)$ & $(0.033)$ & $(0.025)$ & $(0.095)$ & $(0.080)$ & $(0.062)$ & $(0.043)$ \\
\hline \multirow[t]{2}{*}{ SC census pop share } & -0.078 & $-1.255^{* * *}$ & $-1.226^{* *}$ & $-1.436^{* * *}$ & 0.161 & -0.291 & -0.211 & 0.259 \\
\hline & $(0.064)$ & $(0.404)$ & $(0.420)$ & $(0.343)$ & $(0.121)$ & $(0.800)$ & $(0.853)$ & $(0.716)$ \\
\hline \multirow[t]{2}{*}{ ST census pop share } & -0.04 & $-1.458^{* * *}$ & $-1.452^{* * *}$ & $-1.460^{* * *}$ & $-0.347^{* * *}$ & -0.232 & $-0.777^{* *}$ & $-0.760^{* *}$ \\
\hline & $(0.052)$ & $(0.087)$ & $(0.188)$ & $(0.177)$ & $(0.098)$ & $(0.197)$ & $(0.280)$ & $(0.265)$ \\
\hline \multirow[t]{2}{*}{ SC current pop share } & & $1.247^{* *}$ & $1.239 * *$ & $1.421^{* * *}$ & & 0.461 & 0.528 & 0.119 \\
\hline & & $(0.427)$ & $(0.421)$ & $(0.309)$ & & $(0.847)$ & $(0.851)$ & $(0.657)$ \\
\hline \multirow[t]{2}{*}{ ST current pop share } & & $1.208^{* * *}$ & $1.211^{* * *}$ & $1.223^{* * *}$ & & -0.097 & 0.354 & 0.326 \\
\hline & & $(0.075)$ & $(0.173)$ & $(0.154)$ & & $(0.214)$ & $(0.284)$ & $(0.257)$ \\
\hline \multirow[t]{2}{*}{ State income last year } & & & 0.033 & 0.996 & & & -0.898 & $-3.012^{* *}$ \\
\hline & & & $(0.303)$ & $(0.657)$ & & & $(0.531)$ & $(1.016)$ \\
\hline \multirow[t]{2}{*}{ Election year dummy } & & & 0 & -0.079 & & & $-0.795^{*}$ & $-0.622^{*}$ \\
\hline & & & $(0.383)$ & $(0.366)$ & & & $(0.409)$ & $(0.338)$ \\
\hline \multirow[t]{2}{*}{ Rural population share } & & & 0.013 & -0.004 & & & $-0.047^{* *}$ & -0.012 \\
\hline & & & $(0.008)$ & $(0.012)$ & & & $(0.016)$ & $(0.017)$ \\
\hline \multirow[t]{2}{*}{ Total state expenditure } & & & & $-1.321^{*}$ & & & & $2.914^{* * *}$ \\
\hline & & & & $(0.668)$ & & & & $(0.861)$ \\
\hline \multirow[t]{2}{*}{ Constant } & $1.107^{* * *}$ & $2.489^{* * *}$ & 1.171 & $6.152^{* *}$ & $1.428^{* * *}$ & $1.615^{* * *}$ & $12.392^{* *}$ & 1.364 \\
\hline & $(0.159)$ & $(0.188)$ & $(2.478)$ & $(2.797)$ & $(0.307)$ & $(0.413)$ & $(4.847)$ & $(3.357)$ \\
\hline Region and year fixed effects & YES & YES & YES & YES & YES & YES & YES & YES \\
\hline Number of observations & 471 & 471 & 471 & 471 & 476 & 476 & 476 & 476 \\
\hline R-squared & 0.18 & 0.22 & 0.22 & 0.23 & 0.11 & 0.12 & 0.15 & 0.17 \\
\hline
\end{tabular}

Notes: Standard errors clustered by state are in parentheses.

Asterisks denote significance: * significant at $10 \%$; ${ }^{* *}$ significant at $5 \%$; ${ }^{* * *}$ significant at $1 \%$ 
Table 7

Effect of minority political representation on public service delivery

\begin{tabular}{|c|c|c|c|c|c|c|c|c|}
\hline & \multicolumn{4}{|c|}{ Visits by Doctors for Nirodh Distribution } & \multicolumn{4}{|c|}{ Visits by Mobile Medical Units for Nirodh Distribution } \\
\hline & $(1)$ & $(2)$ & $(3)$ & $(4)$ & $(5)$ & $(6)$ & $(7)$ & $(8)$ \\
\hline \multirow[t]{2}{*}{$\mathrm{SC}$ representative share } & $0.131^{* *}$ & 0.101 & 0.121 & 0.122 & -0.137 & -0.124 & -0.086 & -0.08 \\
\hline & $(0.055)$ & $(0.065)$ & $(0.110)$ & $(0.110)$ & $(0.138)$ & $(0.142)$ & $(0.142)$ & $(0.137)$ \\
\hline \multirow[t]{2}{*}{ ST representative share } & $0.146^{* *}$ & $0.247^{* * *}$ & $0.303^{* * *}$ & $0.302^{* * *}$ & $0.375^{* *}$ & $0.313^{* *}$ & $0.459^{* * *}$ & $0.453^{* * *}$ \\
\hline & $(0.057)$ & $(0.063)$ & $(0.055)$ & $(0.055)$ & $(0.163)$ & $(0.144)$ & $(0.067)$ & $(0.063)$ \\
\hline \multirow[t]{2}{*}{ SC census pop share } & $-0.142^{* *}$ & -0.062 & -0.225 & -0.185 & 0.118 & -0.094 & -0.443 & -0.262 \\
\hline & $(0.049)$ & $(0.341)$ & $(0.311)$ & $(0.341)$ & $(0.120)$ & $(0.701)$ & $(0.669)$ & $(0.602)$ \\
\hline \multirow[t]{2}{*}{ ST census pop share } & $-0.134^{* *}$ & $-0.864^{* * *}$ & $-0.915^{* * *}$ & $-0.914^{* * *}$ & $-0.393^{* *}$ & 0.047 & -0.193 & -0.187 \\
\hline & $(0.058)$ & $(0.173)$ & $(0.240)$ & $(0.244)$ & $(0.172)$ & $(0.254)$ & $(0.289)$ & $(0.297)$ \\
\hline \multirow[t]{2}{*}{ SC current pop share } & & -0.062 & 0.079 & 0.044 & & 0.206 & 0.498 & 0.341 \\
\hline & & $(0.367)$ & $(0.371)$ & $(0.388)$ & & $(0.710)$ & $(0.679)$ & $(0.585)$ \\
\hline \multirow[t]{2}{*}{ ST current pop share } & & $0.623^{* * *}$ & $0.629^{* * *}$ & $0.627^{* * *}$ & & -0.375 & -0.248 & -0.259 \\
\hline & & $(0.139)$ & $(0.193)$ & $(0.195)$ & & $(0.259)$ & $(0.274)$ & $(0.273)$ \\
\hline \multirow[t]{2}{*}{ State income last year } & & & -0.577 & -0.758 & & & $-1.301^{*}$ & -2.135 \\
\hline & & & $(0.454)$ & $(0.691)$ & & & $(0.680)$ & $(1.308)$ \\
\hline \multirow[t]{2}{*}{ Election year dummy } & & & 0.088 & 0.102 & & & -0.058 & 0.008 \\
\hline & & & $(0.159)$ & $(0.161)$ & & & $(0.241)$ & $(0.211)$ \\
\hline \multirow[t]{2}{*}{ Rural population share } & & & $-0.046^{* * *}$ & $-0.043^{* *}$ & & & $-0.125^{* * *}$ & $-0.111^{* * *}$ \\
\hline & & & $(0.013)$ & $(0.017)$ & & & $(0.021)$ & $(0.027)$ \\
\hline \multirow[t]{2}{*}{ Total state expenditure } & & & & 0.249 & & & & 1.144 \\
\hline & & & & $(0.820)$ & & & & (1.151) \\
\hline \multirow[t]{2}{*}{ Constant } & $1.080^{* * *}$ & $1.415^{* * *}$ & $9.492^{* *}$ & 8.547 & $1.269^{* * *}$ & $1.159^{*}$ & $21.266^{* * *}$ & $16.957^{* * *}$ \\
\hline & $(0.155)$ & $(0.196)$ & $(3.804)$ & $(5.375)$ & $(0.424)$ & $(0.545)$ & $(5.647)$ & $(5.519)$ \\
\hline Region and year fixed effects & YES & YES & YES & YES & YES & YES & YES & YES \\
\hline Number of observations & 472 & 472 & 472 & 472 & 471 & 471 & 471 & 471 \\
\hline R-squared & 0.05 & 0.06 & 0.07 & 0.07 & 0.07 & 0.08 & 0.14 & 0.15 \\
\hline
\end{tabular}

Notes: Standard errors clustered by state are in parentheses.

Asterisks denote significance: * significant at $10 \%$; ${ }^{* *}$ significant at $5 \%$; ${ }^{* *}$ significant at $1 \%$ 
Table 8

Effect of minority political representation on public service delivery

\begin{tabular}{|c|c|c|c|c|c|c|c|c|}
\hline & \multicolumn{4}{|c|}{ Visits by Doctors for Malaria } & \multicolumn{4}{|c|}{ Visits by Mobile Medical Units for Malaria } \\
\hline & $(1)$ & $(2)$ & $(3)$ & $(4)$ & (5) & $(6)$ & $(7)$ & $(8)$ \\
\hline \multirow[t]{2}{*}{ SC representative share } & $0.228^{* * *}$ & 0.12 & 0.072 & 0.076 & -0.089 & -0.152 & -0.183 & -0.181 \\
\hline & $(0.074)$ & $(0.071)$ & $(0.101)$ & $(0.101)$ & $(0.130)$ & $(0.118)$ & $(0.107)$ & $(0.103)$ \\
\hline \multirow[t]{2}{*}{ ST representative share } & $-0.124^{*}$ & $0.157^{* *}$ & $0.219^{* * *}$ & $0.215^{* * *}$ & $0.321^{* *}$ & $0.396^{* * *}$ & $0.540^{* * *}$ & $0.539 * * *$ \\
\hline & $(0.060)$ & $(0.070)$ & $(0.049)$ & $(0.044)$ & $(0.125)$ & $(0.133)$ & $(0.075)$ & $(0.073)$ \\
\hline \multirow[t]{2}{*}{ SC census pop share } & $-0.230 * * *$ & $-0.682^{*}$ & $-0.688 * *$ & $-0.556^{*}$ & 0.068 & $-1.035^{* *}$ & $-1.315^{* *}$ & $-1.265^{* *}$ \\
\hline & $(0.068)$ & $(0.326)$ & $(0.289)$ & $(0.279)$ & $(0.110)$ & $(0.459)$ & $(0.465)$ & $(0.459)$ \\
\hline \multirow[t]{2}{*}{ ST census pop share } & 0.069 & $-1.979 * * *$ & $-2.247^{* * *}$ & $-2.243^{* * *}$ & $-0.320^{* *}$ & $-0.897 * * *$ & $-1.241^{* * *}$ & $-1.240^{* * *}$ \\
\hline & $(0.059)$ & $(0.166)$ & $(0.223)$ & $(0.219)$ & $(0.133)$ & $(0.263)$ & $(0.298)$ & $(0.298)$ \\
\hline \multirow[t]{2}{*}{ SC current pop share } & & 0.519 & $0.555^{*}$ & 0.441 & & $1.147^{* *}$ & $1.436^{* * *}$ & $1.392^{* * *}$ \\
\hline & & $(0.351)$ & $(0.288)$ & $(0.277)$ & & $(0.419)$ & $(0.469)$ & $(0.456)$ \\
\hline \multirow[t]{2}{*}{ ST current pop share } & & $1.745^{* * *}$ & $1.958^{* * *}$ & $1.951^{* * *}$ & & $0.491^{* *}$ & $0.714^{* *}$ & $0.710^{* *}$ \\
\hline & & $(0.126)$ & $(0.178)$ & $(0.174)$ & & $(0.212)$ & $(0.245)$ & $(0.246)$ \\
\hline \multirow[t]{2}{*}{ State income last year } & & & -0.443 & -1.04 & & & $-1.422^{*}$ & -1.656 \\
\hline & & & $(0.404)$ & $(0.650)$ & & & $(0.675)$ & $(1.330)$ \\
\hline \multirow[t]{2}{*}{ Election year dummy } & & & $-0.393^{*}$ & $-0.346^{*}$ & & & -0.226 & -0.207 \\
\hline & & & $(0.218)$ & $(0.187)$ & & & $(0.370)$ & $(0.371)$ \\
\hline \multirow[t]{2}{*}{ Rural population share } & & & $-0.044 * * *$ & $-0.034 * * *$ & & & $-0.113^{* * *}$ & $-0.109 * * *$ \\
\hline & & & $(0.012)$ & $(0.011)$ & & & $(0.014)$ & $(0.017)$ \\
\hline \multirow[t]{2}{*}{ Total state expenditure } & & & & 0.822 & & & & 0.319 \\
\hline & & & & $(0.564)$ & & & & $(1.069)$ \\
\hline \multirow[t]{2}{*}{ Constant } & $2.384^{* * *}$ & $3.692^{* * *}$ & $10.774^{* * *}$ & $7.657^{* *}$ & $1.182^{* *}$ & $2.085^{* * *}$ & $22.095^{* * *}$ & $20.908^{* * *}$ \\
\hline & $(0.204)$ & $(0.224)$ & $(3.429)$ & $(3.170)$ & $(0.453)$ & $(0.513)$ & $(5.781)$ & $(4.264)$ \\
\hline Region and year fixed effects & YES & YES & YES & YES & YES & YES & YES & YES \\
\hline Number of observations & 472 & 472 & 472 & 472 & 474 & 474 & 474 & 474 \\
\hline R-squared & 0.08 & 0.16 & 0.18 & 0.18 & 0.1 & 0.12 & 0.18 & 0.18 \\
\hline
\end{tabular}

Notes: Standard errors clustered by state are in parentheses.

Asterisks denote significance: * significant at 10\%; ${ }^{* *}$ significant at $5 \%$; ${ }^{* *}$ significant at $1 \%$ 
Table 9

Heterogeneity in effect on public service delivery

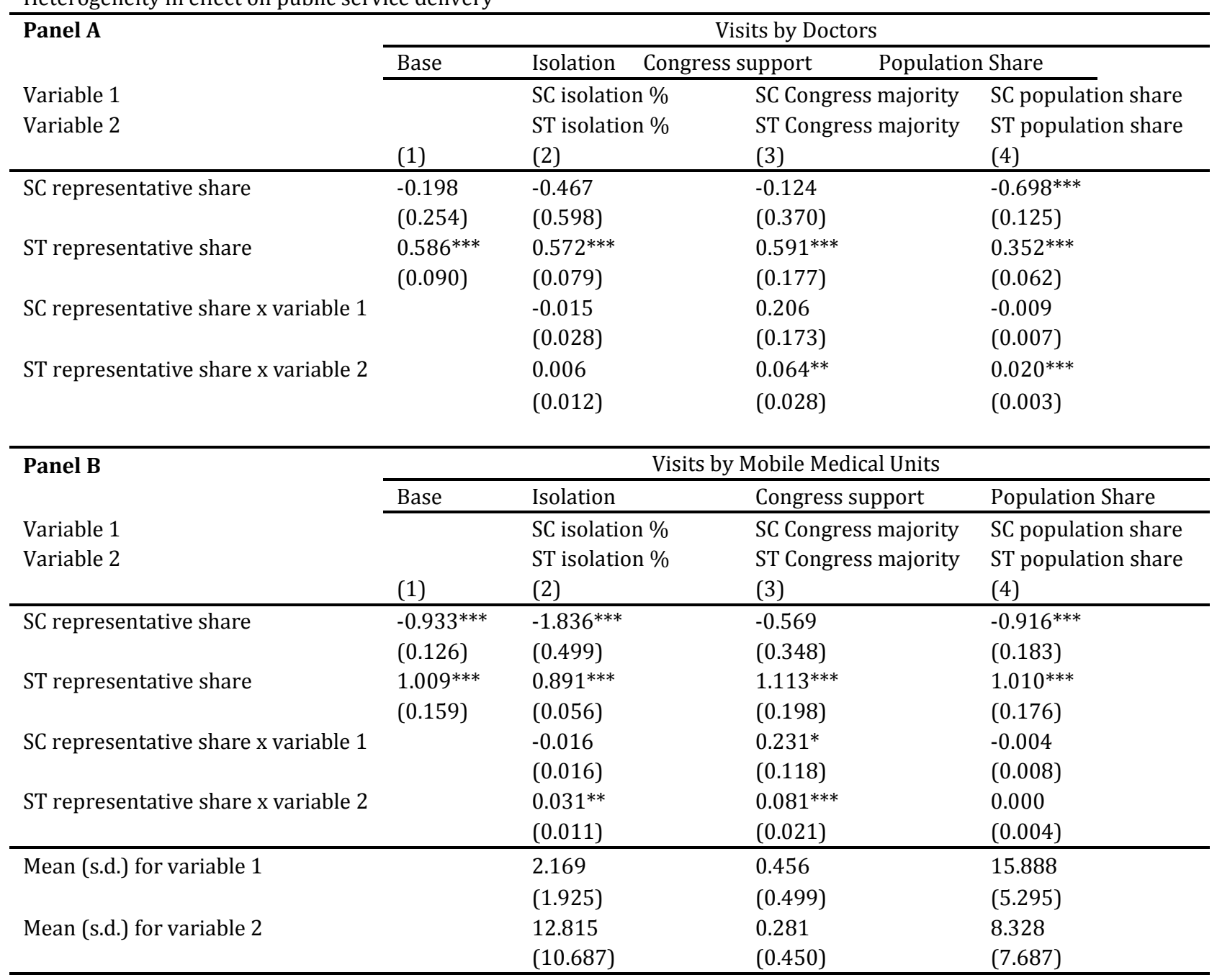

Notes: Standard errors clustered by state are in parentheses. Results displayed in each column come from a separate regression that also controls for region and time fixed effects, SC and ST population shares in the last preceding census, and SC and ST current population shares, state income last year, a dummy for election year, rural population share, and total state expenditure. In addition, the specification in Column 2 controls for Congress Party share of SC, ST and all

Parliament seats.

Asterisks denote significance: * significant at $10 \%$; ** significant at $5 \%$; ** significant at $1 \%$ 


\section{APPENDIX A1}

Table 10

Effect of minority political representation on public service delivery

\begin{tabular}{|c|c|c|c|c|c|c|c|c|}
\hline & \multicolumn{4}{|c|}{ Visits By Doctors to Chlorinate Wells } & \multicolumn{4}{|c|}{ Visits by Mobile Medical Units to Chlorinate Wells } \\
\hline & (1) & $(2)$ & $(3)$ & $(4)$ & $(5)$ & $(6)$ & $(7)$ & $(8)$ \\
\hline \multirow[t]{2}{*}{ SC representative share } & 0.042 & 0 & 0.002 & 0.002 & $-0.153^{* *}$ & $-0.190^{* * *}$ & $-0.292^{* * *}$ & $-0.290^{* * *}$ \\
\hline & $(0.031)$ & $(0.027)$ & $(0.074)$ & $(0.073)$ & $(0.071)$ & $(0.064)$ & $(0.048)$ & $(0.042)$ \\
\hline \multirow[t]{2}{*}{ ST representative share } & 0.01 & $0.147^{* * *}$ & $0.145^{* * *}$ & $0.144^{* * *}$ & $0.285^{* * *}$ & $0.295^{* * *}$ & $0.390^{* * *}$ & $0.387^{* * *}$ \\
\hline & $(0.031)$ & $(0.027)$ & $(0.030)$ & $(0.029)$ & $(0.062)$ & $(0.066)$ & $(0.028)$ & $(0.029)$ \\
\hline \multirow[t]{2}{*}{ SC census pop share } & $-0.081^{* *}$ & 0.024 & 0.031 & 0.042 & $0.139 *$ & $-0.829 * *$ & $-1.031^{* * *}$ & $-0.951^{* * *}$ \\
\hline & $(0.033)$ & $(0.179)$ & $(0.214)$ & $(0.229)$ & $(0.065)$ & $(0.298)$ & $(0.261)$ & $(0.292)$ \\
\hline \multirow[t]{2}{*}{ ST census pop share } & -0.02 & $-1.008^{* * *}$ & $-1.002^{* * *}$ & $-1.002^{* * *}$ & $-0.272^{* * *}$ & $-0.379 * *$ & $-0.657^{* * *}$ & $-0.654^{* * *}$ \\
\hline & $(0.032)$ & $(0.073)$ & $(0.145)$ & $(0.144)$ & $(0.066)$ & $(0.170)$ & $(0.119)$ & $(0.117)$ \\
\hline \multirow[t]{2}{*}{ SC current pop share } & & -0.081 & -0.09 & -0.099 & & $0.996^{* * *}$ & $1.290^{* * *}$ & $1.221^{* * *}$ \\
\hline & & $(0.173)$ & $(0.188)$ & $(0.203)$ & & $(0.266)$ & $(0.271)$ & $(0.296)$ \\
\hline \multirow[t]{2}{*}{ ST current pop share } & & $0.842^{* * *}$ & $0.839 * * *$ & $0.839 * * *$ & & 0.09 & $0.274^{* *}$ & $0.269^{* *}$ \\
\hline & & $(0.060)$ & $(0.113)$ & $(0.114)$ & & $(0.138)$ & $(0.108)$ & $(0.106)$ \\
\hline \multirow[t]{2}{*}{ State income last year } & & & 0.039 & -0.01 & & & $-1.397 * * *$ & $-1.768^{* *}$ \\
\hline & & & $(0.314)$ & $(0.643)$ & & & $(0.320)$ & $(0.631)$ \\
\hline \multirow[t]{2}{*}{ Election year dummy } & & & -0.002 & 0.002 & & & -0.105 & -0.075 \\
\hline & & & $(0.253)$ & $(0.254)$ & & & $(0.192)$ & $(0.184)$ \\
\hline \multirow[t]{2}{*}{ Rural population share } & & & 0.002 & 0.003 & & & $-0.060^{* * *}$ & $-0.054^{* * *}$ \\
\hline & & & $(0.014)$ & $(0.014)$ & & & $(0.008)$ & $(0.009)$ \\
\hline \multirow[t]{2}{*}{ Total state expenditure } & & & & 0.066 & & & & 0.507 \\
\hline & & & & $(0.725)$ & & & & $(0.605)$ \\
\hline \multirow[t]{2}{*}{ Constant } & $1.580^{* * *}$ & $2.031^{* * *}$ & 1.598 & 1.353 & $0.805^{* *}$ & $1.392^{* * *}$ & $16.739^{* * *}$ & $14.836^{* * *}$ \\
\hline & $(0.132)$ & $(0.147)$ & $(3.149)$ & $(3.781)$ & $(0.275)$ & $(0.278)$ & $(2.932)$ & $(2.602)$ \\
\hline Region and year fixed effects & YES & YES & YES & YES & YES & YES & YES & YES \\
\hline Number of observations & 470 & 470 & 470 & 470 & 472 & 472 & 472 & 472 \\
\hline R-squared & 0.06 & 0.09 & 0.09 & 0.09 & 0.13 & 0.14 & 0.17 & 0.17 \\
\hline
\end{tabular}

Notes: Standard errors clustered by state are in parentheses.

Asterisks denote significance: * significant at $10 \%$; ** significant at $5 \%$; ** significant at $1 \%$ 
Table 11

Effect of minority political representation on public service delivery

\begin{tabular}{|c|c|c|c|c|c|c|c|c|}
\hline & \multicolumn{4}{|c|}{ Visits By Doctors for Blindness Prevention } & \multicolumn{4}{|c|}{ Visits by Mobile Medical Units for Blindness Prevention } \\
\hline & (1) & (2) & (3) & (4) & (5) & (6) & (7) & (8) \\
\hline \multirow[t]{2}{*}{ SC representative share } & -0.015 & -0.028 & 0.142 & 0.133 & $-0.225^{* *}$ & $-0.219^{* *}$ & $-0.295^{* *}$ & $-0.291^{* * *}$ \\
\hline & $(0.086)$ & $(0.100)$ & $(0.140)$ & $(0.146)$ & $(0.078)$ & $(0.083)$ & $(0.100)$ & $(0.089)$ \\
\hline \multirow[t]{2}{*}{ ST representative share } & $0.367^{* *}$ & $0.328^{* *}$ & $0.411^{* * *}$ & $0.420^{* * *}$ & $0.292^{* * *}$ & $0.248^{* *}$ & $0.297^{* * *}$ & $0.293^{* * *}$ \\
\hline & $(0.142)$ & $(0.138)$ & $(0.055)$ & $(0.063)$ & $(0.090)$ & $(0.099)$ & $(0.080)$ & $(0.076)$ \\
\hline \multirow[t]{2}{*}{ SC census pop share } & -0.008 & -0.722 & $-0.968^{* *}$ & $-1.267^{* * *}$ & $0.197^{* *}$ & -0.049 & 0.02 & 0.175 \\
\hline & $(0.062)$ & $(0.434)$ & $(0.397)$ & $(0.233)$ & $(0.069)$ & $(0.423)$ & $(0.476)$ & $(0.424)$ \\
\hline \multirow[t]{2}{*}{ ST census pop share } & $-0.373^{* *}$ & -0.117 & -0.098 & -0.107 & $-0.326^{* * *}$ & -0.019 & -0.329 & -0.324 \\
\hline & $(0.149)$ & $(0.230)$ & $(0.246)$ & $(0.234)$ & $(0.093)$ & $(0.244)$ & $(0.283)$ & $(0.286)$ \\
\hline \multirow[t]{2}{*}{ SC current pop share } & & 0.726 & $0.790^{*}$ & $1.050^{* * *}$ & & 0.244 & 0.23 & 0.096 \\
\hline & & $(0.454)$ & $(0.435)$ & $(0.246)$ & & $(0.427)$ & $(0.475)$ & $(0.419)$ \\
\hline \multirow[t]{2}{*}{ ST current pop share } & & -0.219 & -0.277 & -0.259 & & -0.262 & 0.001 & -0.008 \\
\hline & & $(0.190)$ & $(0.209)$ & $(0.190)$ & & $(0.181)$ & $(0.231)$ & $(0.236)$ \\
\hline \multirow[t]{2}{*}{ State income last year } & & & -0.141 & 1.216 & & & -0.306 & -1.007 \\
\hline & & & $(0.453)$ & $(1.039)$ & & & $(0.394)$ & $(0.749)$ \\
\hline \multirow[t]{2}{*}{ Election year dummy } & & & 0.079 & -0.029 & & & $-0.523^{*}$ & $-0.467^{*}$ \\
\hline & & & $(0.215)$ & $(0.230)$ & & & $(0.245)$ & $(0.242)$ \\
\hline \multirow[t]{2}{*}{ Rural population share } & & & $-0.095^{* * *}$ & $-0.118^{* * *}$ & & & $-0.031^{* *}$ & -0.019 \\
\hline & & & $(0.022)$ & $(0.026)$ & & & $(0.013)$ & $(0.013)$ \\
\hline \multirow[t]{2}{*}{ Total state expenditure } & & & & $-1.868^{*}$ & & & & 0.965 \\
\hline & & & & $(0.927)$ & & & & $(0.689)$ \\
\hline \multirow[t]{2}{*}{ Constant } & $1.276^{* * *}$ & $1.534^{* * *}$ & $10.619^{* * *}$ & $17.691^{* * *}$ & $1.438^{* * *}$ & $1.414^{* * *}$ & $6.435^{*}$ & 2.78 \\
\hline & $(0.390)$ & $(0.497)$ & $(3.461)$ & $(3.897)$ & $(0.183)$ & $(0.311)$ & $(3.496)$ & $(2.881)$ \\
\hline Region and year fixed effects & YES & YES & YES & YES & YES & YES & YES & YES \\
\hline Number of observations & 473 & 473 & 473 & 473 & 474 & 474 & 474 & 474 \\
\hline R-squared & 0.2 & 0.21 & 0.26 & 0.27 & 0.16 & 0.16 & 0.18 & 0.19 \\
\hline
\end{tabular}

Notes: Standard errors clustered by state are in parentheses.

Asterisks denote significance: * significant at $10 \%$; ** significant at $5 \%$; ${ }^{* * *}$ significant at $1 \%$ 
Table 12

Effect of minority political representation on public service delivery

\begin{tabular}{|c|c|c|c|c|c|c|c|c|}
\hline & \multicolumn{4}{|c|}{ Visits By Doctors for General Education } & \multicolumn{4}{|c|}{ Visits by Mobile Medical Units for General Education } \\
\hline & $(1)$ & $(2)$ & $(3)$ & $(4)$ & $(5)$ & $(6)$ & $(7)$ & $(8)$ \\
\hline SC representative share & $\begin{array}{l}0.148^{* *} \\
(0.057)\end{array}$ & $\begin{array}{l}0.099 \\
(0.065)\end{array}$ & $\begin{array}{l}0.177^{*} \\
(0.091)\end{array}$ & $\begin{array}{l}0.178^{*} \\
(0.090)\end{array}$ & $\begin{array}{l}-0.218^{*} \\
(0.110)\end{array}$ & -0.198* & -0.111 & -0.117 \\
\hline ST representative share & $\begin{array}{l}0.022 \\
(0.048)\end{array}$ & $\begin{array}{l}0.130 * * \\
(0.048)\end{array}$ & $\begin{array}{l}0.122^{* * *} \\
(0.041)\end{array}$ & $\begin{array}{l}0.121^{* *} \\
(0.041)\end{array}$ & $\begin{array}{l}0.337^{* *} \\
(0.132)\end{array}$ & $\begin{array}{l}0.262^{*} \\
(0.123)\end{array}$ & $\begin{array}{l}0.341^{* * *} \\
(0.059)\end{array}$ & $\begin{array}{l}0.348^{* * *} \\
(0.055)\end{array}$ \\
\hline SC census pop share & $\begin{array}{l}-0.133^{* *} \\
(0.060)\end{array}$ & $\begin{array}{l}-0.513 \\
(0.324)\end{array}$ & $\begin{array}{l}-0.452 \\
(0.348)\end{array}$ & $\begin{array}{l}-0.401 \\
(0.411)\end{array}$ & $\begin{array}{l}0.201^{* *} \\
(0.089)\end{array}$ & $\begin{array}{l}0.093 \\
(0.496)\end{array}$ & $\begin{array}{l}-0.125 \\
(0.500)\end{array}$ & $\begin{array}{l}-0.319 \\
(0.417)\end{array}$ \\
\hline ST census pop share & $\begin{array}{l}-0.004 \\
(0.043)\end{array}$ & $\begin{array}{l}-0.799 * * * \\
(0.095)\end{array}$ & $\begin{array}{l}-0.759 * * * \\
(0.165)\end{array}$ & $\begin{array}{l}-0.757^{* * *} \\
(0.162)\end{array}$ & $\begin{array}{l}-0.350^{* *} \\
(0.139)\end{array}$ & $\begin{array}{l}0.186 \\
(0.208)\end{array}$ & $\begin{array}{l}0.135 \\
(0.227)\end{array}$ & $\begin{array}{l}0.128 \\
(0.213)\end{array}$ \\
\hline SC current pop share & & $\begin{array}{l}0.412 \\
(0.350)\end{array}$ & $\begin{array}{l}0.268 \\
(0.369)\end{array}$ & $\begin{array}{l}0.223 \\
(0.420)\end{array}$ & & $\begin{array}{l}0.096 \\
(0.475)\end{array}$ & $\begin{array}{l}0.217 \\
(0.490)\end{array}$ & $\begin{array}{l}0.385 \\
(0.393)\end{array}$ \\
\hline ST current pop share & & $\begin{array}{l}0.678^{* * *} \\
(0.093)\end{array}$ & $\begin{array}{l}0.659^{* * *} \\
(0.144)\end{array}$ & $\begin{array}{l}0.656^{* * * *} \\
(0.138)\end{array}$ & & $\begin{array}{l}-0.457^{* *} \\
(0.181)\end{array}$ & $\begin{array}{l}-0.456^{* *} \\
(0.208)\end{array}$ & $\begin{array}{l}-0.444^{* *} \\
(0.202)\end{array}$ \\
\hline State income last year & & & $\begin{array}{l}0.605 \\
(0.450)\end{array}$ & $\begin{array}{l}0.371 \\
(0.995)\end{array}$ & & & $\begin{array}{l}-0.456 \\
(0.546)\end{array}$ & $\begin{array}{l}0.432 \\
(1.020)\end{array}$ \\
\hline Election year dummy & & & $\begin{array}{l}-0.121 \\
(0.176)\end{array}$ & $\begin{array}{l}-0.102 \\
(0.161)\end{array}$ & & & $\begin{array}{l}0.047 \\
(0.191)\end{array}$ & $\begin{array}{l}-0.026 \\
(0.239)\end{array}$ \\
\hline Rural population share & & & $\begin{array}{l}-0.007 \\
(0.020)\end{array}$ & $\begin{array}{l}-0.003 \\
(0.021)\end{array}$ & & & $\begin{array}{l}-0.078^{* * *} \\
(0.025)\end{array}$ & $\begin{array}{l}-0.092^{* * *} \\
(0.025)\end{array}$ \\
\hline Total state expenditure & & & & $\begin{array}{l}0.321 \\
(1.023)\end{array}$ & & & & $\begin{array}{l}-1.217 \\
(0.811)\end{array}$ \\
\hline Constant & $\begin{array}{l}0.924^{* * *} \\
(0.264)\end{array}$ & $\begin{array}{l}1.545^{* * *} \\
(0.245)\end{array}$ & $\begin{array}{l}-2.24 \\
(4.389)\end{array}$ & $\begin{array}{l}-3.447 \\
(4.784)\end{array}$ & $\begin{array}{l}1.410^{* * *} \\
(0.366)\end{array}$ & $\begin{array}{l}1.191^{* *} \\
(0.440)\end{array}$ & $\begin{array}{l}11.085^{* *} \\
(5.026)\end{array}$ & $\begin{array}{l}15.653^{* * *} \\
(4.128)\end{array}$ \\
\hline $\begin{array}{l}\text { Region and year fixed } \\
\text { effects }\end{array}$ & YES & YES & YES & YES & YES & YES & YES & YES \\
\hline Number of observations & 473 & 473 & 473 & 473 & 475 & 475 & 475 & 475 \\
\hline R-squared & 0.1 & 0.11 & 0.12 & 0.12 & 0.13 & 0.13 & 0.17 & 0.17 \\
\hline
\end{tabular}

Notes: Standard errors clustered by state are in parentheses.

Asterisks denote significance: * significant at $10 \%$; ${ }^{* *}$ significant at $5 \%$; ${ }^{* *}$ significant at $1 \%$ 
Table 13

Effect of minority political representation on public service delivery

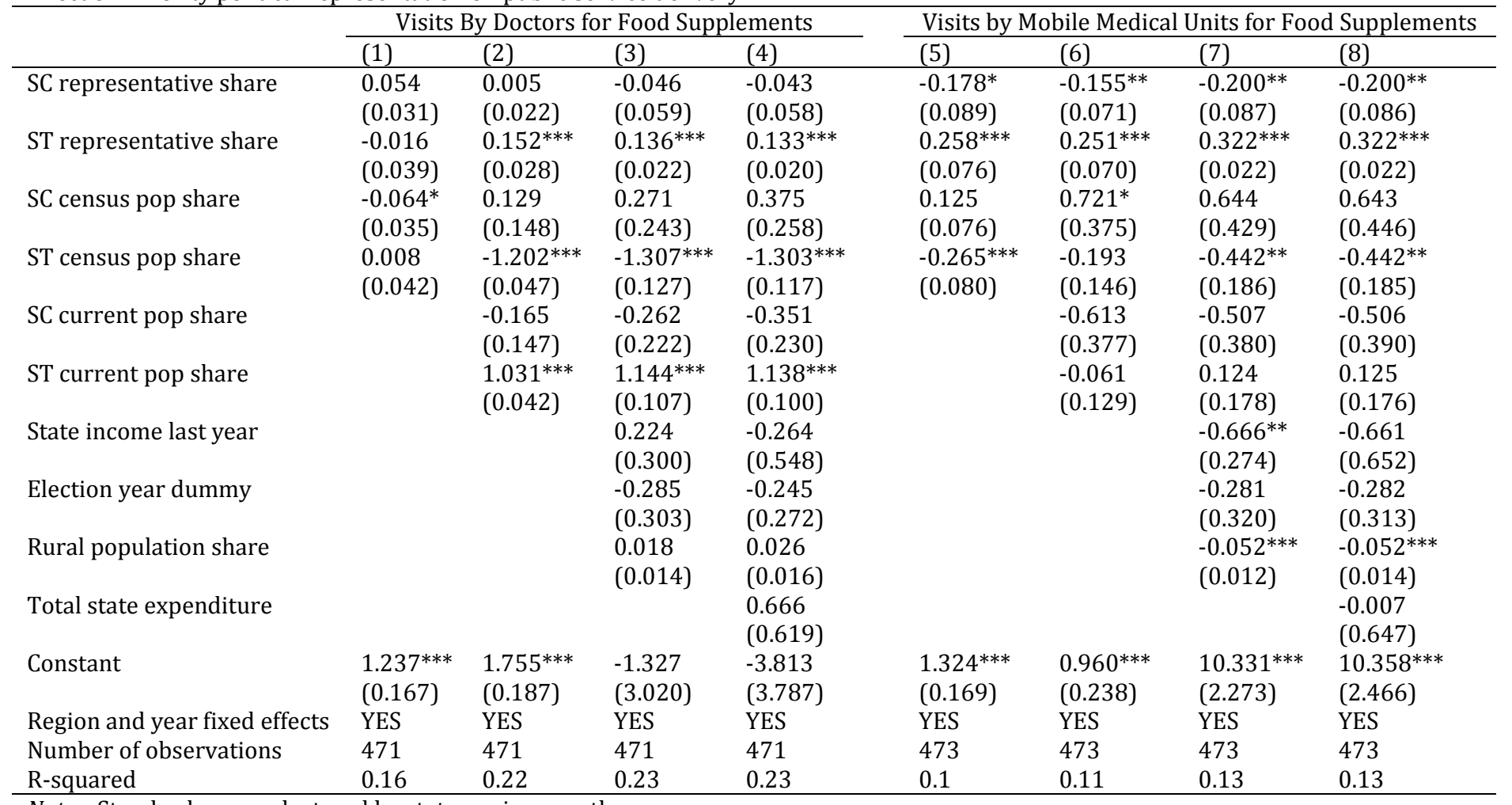

Notes: Standard errors clustered by state are in parentheses.

Asterisks denote significance: * significant at 10\%; ** significant at $5 \%$; *** significant at $1 \%$ 